\title{
Lycopodiaceae in Brazil. Conspectus of the family II. The genera Lycopodiella, Palhinhaea, and Pseudolycopodiella
}

\author{
Benjamin Øllgaard ${ }^{1,3} \&$ Paulo G. Windisch ${ }^{2}$
}

\begin{abstract}
This paper treats the Brazilian species of three genera of the Lycopodiaceae: Lycopodiella with four species (one endemic), Palhinhaea with six (two endemics), and Pseudolycopodiella with seven (one endemic). The species are described, and keys and illustrations, or references to illustrations for their identification are provided. The nomenclature is reviewed. Representative specimens are cited, and the general distribution and habitats are indicated. Pseudolycopodiella squamata is described as new to science.
\end{abstract}

Key words: diversity, floristics, lycophytes, phytogeography, taxonomy.

\section{Resumo}

Este trabalho trata as espécies de três gêneros de Lycopodiaceae: Lycopodiella com quatro espécies (uma endêmica), Palhinhaea com seis (duas endêmicas) e Pseudolycopodiella com sete (uma endêmica). As espécies são descritas, sendo apresentadas chaves e ilustrações ou referências a ilustrações para sua identificação. A nomenclatura está revisada, espécimes representativos são citados, a distribuição geral e habitats são indicados. Pseudolycopodiella squamata é descrita como nova para a ciência.

Palavras-chave: diversidade, florística, licófitas, fitogeografia, taxonomia.

\section{Introduction}

This is the second part of a series of treatments of the Brazilian Lycopodiaceae. It deals with the genera Lycopodiella, Palhinhaea, and Pseudolycopodiella, including a total of 17 species. The first part (Øllgaard \& Windisch 2014) treated the genera Austrolycopodium, Diphasiastrum, Diphasium, and Lycopodium, including five species, and gave a general introduction to the family, the history of its study and exploration in Brazil, and keys to the genera of the whole family.

The three genera treated here correspond to the subfamily Lycopodielloideae of Wagner \& Beitel (1992), validated by Øllgaard (2014), and the genus Lycopodiella Holub s. lat. (sensu Øllgaard 1987).
In addition to these three genera, the genus Lateristachys Holub (1983) (Australia, New Zealand, Tasmania, New Caledonia, and the Philippines) belongs to the Lycopodielloideae.

\section{Material and Methods}

The methodology used in this study was the same adopted by the fist part of this treatment (Øllgaard \& Windisch 2014).

\section{Taxonomic treatment}

The genera treated in the present study can be distinguished from the remaining of Lycopodiaceae genera occuring in Brazil based on the characters presented in the following key.

\footnotetext{
'University of Aarhus, Institute for Bioscience, build. 1137, DK 8000 Aarhus C., Denmark.

${ }^{2}$ Universidade Federal do Rio Grande do Sul, Inst. Biociências, PPG Botânica, 91501-970, Porto Alegre, RS, Brazil.

${ }^{3}$ Author for correspondence: benjamin.oellgaard@biology.au.dk
} 


\section{Key to Brazilian genera of Lycopodiaceae}

1. Stems isotomously branched throughout, without elongate, indeterminate main stems, but sometimes heteroblastic, roots usually forming one basal tuft, sporophylls and vegetative leaves alike, or the sporophylls, if smaller, persisting and green, not subpeltate and ephemeral; spores foveolate-fossulate Huperzia and Phlegmariurus

1'. Stems anisotomously branched throughout, the branches differentiated into elongate, indeterminate, rhizomatous, or creeping, trailing, or climbing main stems, and usually determinate branchlet systems; sporophylls strongly modified, ephemeral, unlike vegetative leaves, peltate or subpeltate, aggregated in compact, terminal strobili.

2. Strobili erect, sessile or pedunculate, borne on branchlet systems which arise in a dorso-lateral position on the main stem; side walls of sporangium epidermis cells sinuate, lignified throughout; spores reticulate....................... Austrolycopodium, Diphasiastrum, Diphasium, and Lycopodium

2'. Strobili pendulous and sessile, - or strobili erect and terminating simple or to twice forked branches which arise dorsally on the creeping stem (but see Palhinhaea bradei); sidewalls of sporangium epidermis cells straight, non-lignified, except for nodular or semi-annular lignified thickenings; spores rugate.

3. Strobili pendent or nodding, terminating amply branched branchlet systems which are borne on an erect or scandent-trailing, tree-like main branch, - or rarely (P. bradei) strobili ascending, borne on low, ascending, somewhat fan-shaped branchlet systems, lacking an erect main branch; sporangia remaining partly enclosed in cavities formed by the strobilus cortex and coalescent membranous bases of adjacent sporophylls; sporangium walls with nodular lignified thickenings..... Palhinhaea

3'. Strobili erect, terminating simple or forked erect branches (peduncles) that arise dorsally on the creeping stem; sporophylls free, sporangia not enclosed in cavities at maturity. Sporangium walls with semiannular lignified thickenings.

4. Sporophylls nearly twice as wide as adjacent peduncle leaves or wider, ovate to ovatelanceolate, of different colour and texture than peduncle leaves, the margins minutely rugose to minutely fimbriate-denticulate, usually to $10(-12)$-seriate; sporangia isovalvate, attached to the upper side of the sporophyll; creeping shoots isophyllous to strongly anisophyllous, with wide and long lateral leaves and narrow dorsal leaves; sporangium epidermis cells with incompletely lignified semiannular thickenings

4'. Sporophylls slightly wider to ca. 1.5 times wider than adjacent peduncle leaves and of the same colour and texture, linear-lanceolate to ovate- lanceolate, with few to several sharp, long and often recurved teeth, (10-) 12-20-seriate; sporangia anisovalvate, axillary; creeping shoots isophyllous or nearly so; sporangium epidermis cells with completely lignified semiannular thickenings ...... Lycopodiella s. str.

Lycopodiella Holub s. str., Preslia 36: 22. 1964. - Type: Lycopodiella inundata (L.) Holub (=Lycopodium inundatum L.).

Lycopodium subgen. Rhopalostachya Pritzel sect. Inundata Pritzel, Nat. Pflanzenfam. 1(4): 601. 1901. - Lycopodium subgen. Lycopodiella (Holub) B. Øllg., Amer. Fern J. 69: 49. 1979. - Lycopodium subgen. Inundatistachys Herter, Bot. Jahrb. 43: Beibl. 98: 29. 1909.

Sporophytes with prostrate or looping, rooting, indeterminate stems, isophyllous to slightly anisophyllous, horizontally branching shoots, and dorsally arising, erect, simple or to three times forked strobiliferous branches; leaves of erect branches conform with leaves of prostrate shoots, or somewhat reduced; sporophylls arranged in alternating whorls of 5 or more, forming 10 or more longitudinal ranks, free, not enclosing the sporangia in cavities at maturity, subpeltate, with triangular cross-section of the immature stalk, with veinal and basal mucilage canals; sporangia axillary, transversely oblong, with a narrow stalk, anisovalvate; sporangium epidermis cells with semiannular, lignified thickenings; $\mathrm{x}=78$.

Northern temperate regions, Tropical America south to Northern Argentina. Twelve or more species. Several interspecific hybrids are known in North 
America, where the hybrids between homoploid species form normal spores (Bruce 1975). The sporophylls of Lycopodiella have been repeatedly indicated to be similar to the leaves, and the genus was therefore assumed to be more primitive than those of the other strobiliferous groups (e.g., Pritzel 1901). Their similarity is only superficial, however. The sporophylls have a distinctly subpeltate base, containing a well developed basal mucilage canal (Bruce 1976).

The South American representatives of the genus were earlier referred to Lycopodiella alopecuroides (L.) Holub, but this species sensu stricto is limited to North America and Cuba.

Nessel $(1927,1955)$ treated the Brazilian material under Lycopodium alopecuroides with several varieties. However, few of these were based on relevant features, and some were included in the Brazilian flora on the basis of mislabelled North American material in his private herbarium. Nessel included all Brazilian material belonging in Lycopodiella in one species, and in 1927 also Pseudolycopodiella contexta, following Christ (1902).

\section{Key to the species of Lycopodiella in Brazil}

1. Main horizontal stem arching to looping, rooting with long intervals at soil contact, or rarely partly creeping and rooting closely; the laterally arising minor branchlet systems ascending to erect, subequally forking, with ascending to appressed leaves throughout; strobiliferous branch simple or to 3 times forked Lycopodiella geometra

1'. Main horizontal stem and its minor branches closely appressed to the ground, with patent-ascending to perpendicular, often slightly anisophyllous leaves; strobiliferous branch simple (rarely forked, or the strobilus rarely branched).

2. Strobili $15-25 \mathrm{~mm}$ thick incl. sporophylls, sporophylls 9-13 mm long, vegetative leaves of erect branch $8-10 \mathrm{~mm}$ long..... Lycopodiella duseniana

2'. Strobili 6-15 mm thick incl. sporophylls, sporophylls 3.5-9 mm long, vegetative leaves of erect branch 4-7 mm long.

3. Strobili with spreading to loosely appressed, linear-lanceolate to lanceolate, 5-7 (-9) $\mathrm{mm}$ long sporophylls, $8-15 \mathrm{~mm}$ thick incl. sporophylls; leaves of horizontal shoots with smooth to long-ciliate or coarsely dentate margins Lycopodiella longipes

3'. Strobili with loosely to closely appressed, lanceolate to ovate and cuspidate, $3.5-6 \mathrm{~mm}$ long sporophylls; 5-10 mm thick incl. sporophylls, leaves of horizontal shoots with smooth to minutely denticulate margins ..... Lycopodiella tupiana

Lycopodiella duseniana (B. Øllg. \& P.G. Windisch) B. Øllg., Rodriguesia 63: 479. 2012.

Fig. 1

Lycopodiella alopecuroides var. duseniana B. Øllg. \& P.G. Windisch, Bradea 5: 29, fig. 4d. 1987. - Type: Brasil: estado do Rio de Janeiro, Itatiaia, Retiro, P. Dusén 165 (S holotype).

Illustrations: Nessel, in Hoehne, Fl. Bras. fasc. 11 (II:II): 97, fig. 79. 1955, as Lycopodium alopecuroides var. juergensii Rosenst.

Horizontal shoot system creeping, rooted with short intervals, bearing laterally arising, sparsely ramified dichotomous branchlet systems, and dorsally arising, stiffly erect, simple, to $25(-35) \mathrm{cm}$ tall strobiliferous branches. Main branch of horizontal shoot system to at least 40 $\mathrm{cm}$ long, covered by patent to loosely upward curved leaves, $8-18 \mathrm{~mm}$ diam. incl. leaves,
1.5-3 mm thick excl. leaves. Leaves of creeping branches usually flat, often somewhar upward secund, linear-subulate, $5-10 \times$ ca. $0.7-1 \mathrm{~mm}$, with smooth margins. Strobiliferous branches with patent-ascending to somewhat appressed leaves, ca. 5-15 mm diam. incl. leaves, 1.5-2.5 $\mathrm{mm}$ thick excl. leaves. Leaves of strobiliferous branches borne in irregular, alternating low spirals or whorls of 5-7, forming 10-14 indistinct longitudinal ranks, essentially conform with those of horizontal main branch, or sometimes with a few long spreading teeth. Strobili 6-13 $\times$ $1.5-2.5 \mathrm{~cm}$ incl. sporophylls Sporophylls borne in altenating whorls of 7-9, forming 14-18 indistinct longitudinal ranks, linear-lanceolate to lanceolate, with coarse pluricellular, spreading to hooked teeth on the margin, $7-12 \times 1-1.2 \mathrm{~mm}$. Sporangia ca. $1 \mathrm{~mm}$ wide. 
Collections studied: BRAZIL. MINAS GERAIS: Parque Nacional do Caparaó, 2000 m, Krieger et al. (CESJ 24180). RIO DE JANEIRO: Serra dos Orgãos, Campo de Antas, 2000 m, Rizzini 663 (RB). Crête des Orgues, ouest de la source du Rio Soberbo, Glaziou 4481 (P). Teresópolis, Campo das Antas, Emygdio 942 (R). Teresópolis, Serra dos Orgãos, Pedra do Sino, Sylvestre et al. 1926 (RB). Campo Itatiaia (Várzeas), Luederwaldt 7420 (SP). Itatiaia, Retiro, Dusén 166 (R). Itatiaia, Serra da Pedra Assentada, Dusén 1134 (S). Itatiaia, Lagoa das Prateleiras, Brade 15567 (AAU, RB, S). Itatiaia, Lagoa da Base, Campos Porto 2601 (RB). Itatiaia, $2250 \mathrm{~m}$, Brade et al. 6510 (HB, S, SP). Itatiaia, Planalto, 2350 m, Barcia 1194 (R). Itatiaia, trilha para o Pico das Agulhas Negras, 2400 m, Condack, 410 (RB). PARANÁ: Capão Grande, Dec. 1903, Dusén (S).

Distribution and habitat: Endemic to Southeastern and Southern Brazil. States of Minas Gerais, Rio de Janeiro, Paraná. Limited to wet, grassy high-altitude communities, campo do altitude. 2000-2400 m.

Differs from Lycopodiella longipes by its generally shorter strobiliferous branches (to ca. $30 \mathrm{~cm}$ tall) and stouter growth habit, longer, and wider, entire, vegetative leaves, thick strobili, and long sporophylls.

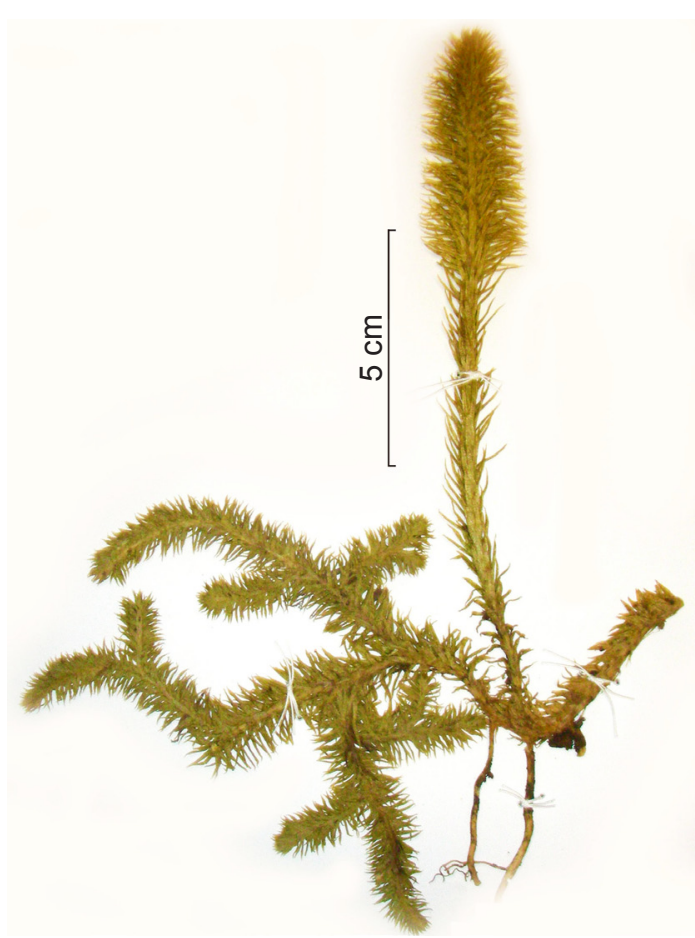

Figure 1 - Lycopodiella duseniana. Brazil, Rio de Janeiro, P.N. Itatiaia, Agulhas Negras, 2400 m, Condack 410 (RB).
Lycopodiella geometra B. Øllg. \& P.G. Windisch, Bradea 5: 30. 1987.

Fig. 2

Type: Brazil: Est. Minas Gerais: mun. Santana do Riacho, estrada de Lagoa Santa a Conceição do Mato Dentro, Km 132 (antigo), Serra do Cipó, campo rupestre, entre gramineas, alt. ca. 1250 m, 2 Feb. 1987, J. Prado et al. 80 (HB holotype, AAU, SP, SPF isotypes).

Lycopodium alopecuroides L. var. furcatum Fée, Crypt. vasc. Brésil. I: 223. 1869. - Type: Warming s.n., Brazil, Minas Gerais, Lagoa Santa, 1866 (C).

Lycopodium alopecuroides L. var. hoehneanum Nessel, Arch. Bot. Est. S. Paulo 1: 430, t. 37. 1927. - Types: 6 collections from SP cited: Hoehne s.n., Brazil, São Paulo, Pinheiros, 30/8/917 (SP 469, lectotype, here selected, illustrated in protologue).

Illustrations: Nessel in Hoehne, Fl. Bras. fasc. 11 (II:II): 1955: fig. 85, 86, 89, as Lycopodium alopecuroides var. longipes, and L. alopecuroides var. hoehneanum.

Horizontal shoot system arching to looping, rooted with long intervals at soil contact, or partly creeping and rooting closely, bearing laterally arising, erect, to several times subequally forked branchlet systems, and dorsally arising, stiffly erect, simple or to 3 times subequally dichotomous, at least to $50 \mathrm{~cm}$ tall strobiliferous branches. Main branch of horizontal shoot system to at least $70 \mathrm{~cm}$ long, covered by ascending to loosely appressed leaves, (4-) 5-10 mm diam. incl. leaves, 2.5-6 (-10) mm thick excl. leaves, inundated stem portions often swollen. Main branch leaves usually flat, subulate, 5-8 $\times$ ca. 0.8-1 mm, with coarse, spreading to hooked marginal teeth. Laterally arising erect branchlet systems at least to $25 \mathrm{~cm}$ high, to at least 4 times dichotomous. Ultimate branchlets 3-8 $\mathrm{mm}$ diam. incl. leaves, 0.7-1.5 $\mathrm{mm}$ diam. excl. leaves. Branchlet leaves ascending, arcuate-ascending to arcuate-appressed, densely crowded, concealing the stem, subulate, usually abaxially convex, (2.5-) 4-6 × 0.5-0.8 (-1) mm, with few (or some without) to many spreading teeth, often with a slightly thickened, pale, smooth apex. Strobiliferous branches with uniformly appressed leaves, 5-10 $\mathrm{mm}$ diam. incl. leaves, 2-5 $\mathrm{mm}$ thick excl. leaves, borne in irregular, alternating low spirals or whorls of 8-10, forming 16-20 indistinct longitudinal ranks, essentially conform with those of horizontal main branch. Strobili to $18 \mathrm{~cm}$ long, 8-20 mm diam. Sporophylls borne in 


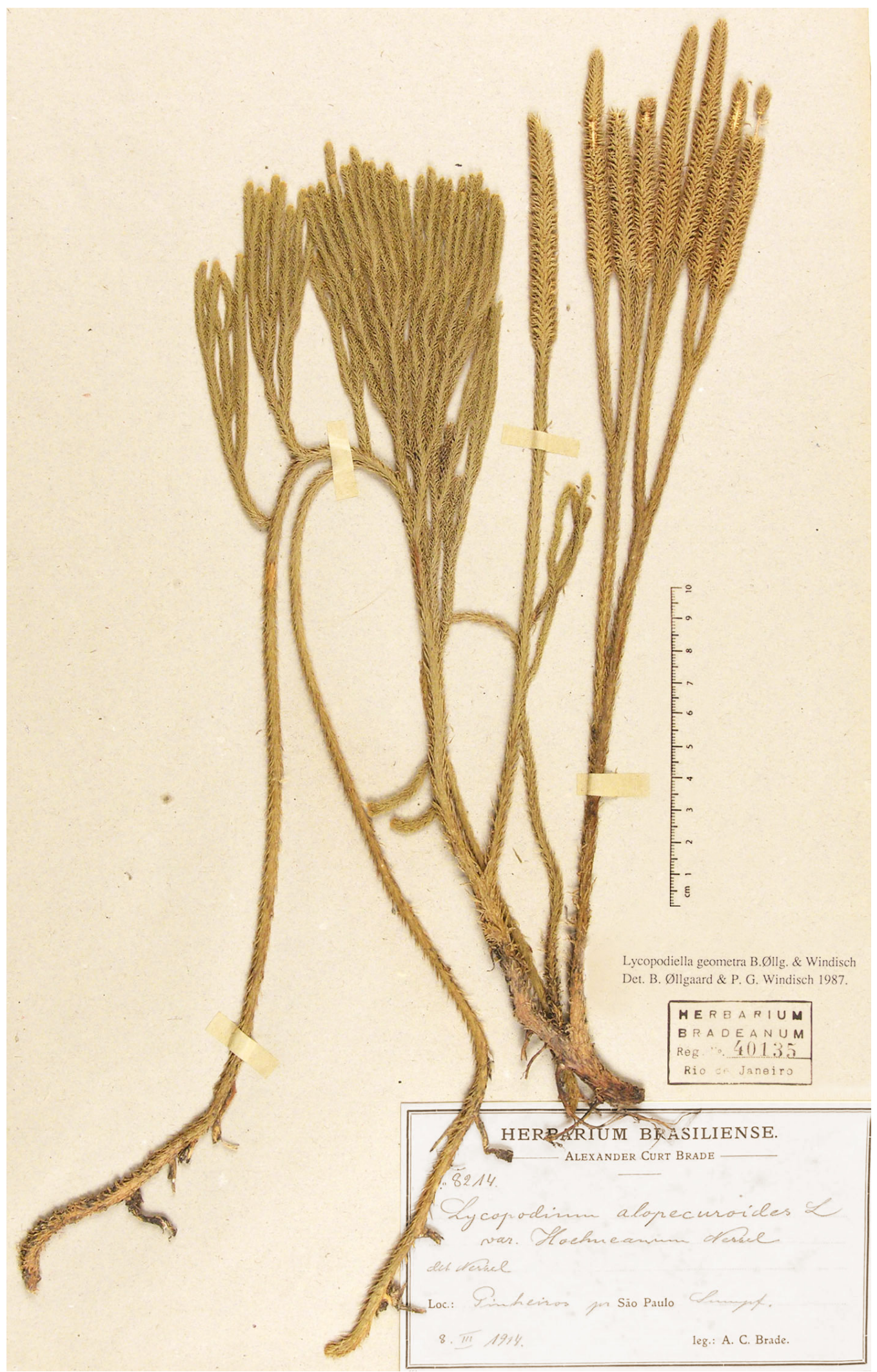

Figure 2 - Lycopodiella geometra. Brazil, São Paulo, Pinheiros, Brade 8214 (HB). 
altenating whorls of 6-10, forming 12-20 indistinct longitudinal ranks, with narrow transverse and basiscopic wings on the stalk, linear-lanceolate to lanceolate, with coarse pluricellular, spreading to hooked teeth on the margin, (4-) 5-10 × 1-1.5 (-2) $\mathrm{mm}$. Sporangia ca. $1 \mathrm{~mm}$ wide.

Reference specimens (more than 80 collections studied, complete listing available from the main author): BRAZIL. BAHIA: Löfgren 510 (S). MATO GROSSO: Tapirapoan, Hoehne 1487 (R). MINAS GERAIS: Betim, Contagem, Fazenda Cambuí, Williams 5116 (GH). Serra do Cipó, 1200-1300 m, Maguire et al. 49068 (GH). S. Sebastião do Paraiso, Brade 17931 (RB). Ibitipoca, Parque Estadual da Serra de Ibitipoca, Pita 282 (AAU, SPF). Pouso Alegre, Hoehne 19337 (NY, SP). PARANÁ: Headwaters of Rio Irati, Hatschbach 13686 (Z). Serra da Esperança, Brade 19723 (AAU, RB). Tijucas do Sul, Serra de Araçatuba, Kummrow 571 (MO). RIO DE JANEIRO: Nova Friburgo, Dusen 1904 (S). Near Rio de Janeiro, Glaziou 11720 (E). RIO GRANDE DO SUL: Venâncio Ayres, Jürgens \& Stier, in Rosenstock: Fil. Austrobras. exsicc. 252 (E, RB, U, UC, US). Ibid., $252 a$ (E, RB, S). Bom Jesus, Fazenda Carauna, Dutra 1206 (ICN, R). São Francisco de Paula, Windisch et al. 10.000 (PACA). SANTA CATARINA: Mafra, W of Tinguí, 800 m, Smith \& Klein 10612 (US). Porto União, 750 m, Smith \& Klein 8725 (US). Lages. Sehnem 5530 (HBR, PACA). Campo Alegre, Morro Iquererim, Reitz \& Klein 6115 (HB). SÃO PAULO: Paraguaçu Paulista, 500$550 \mathrm{~m}$, Eiten et al. 5888 (GH, MO, SP, US). S. Bernardo, Brade 5131 (HB, S). Vila Ema-São Caetano, Brade 15693 (AAU, RB). Campos do Jordão, Lanstyack (RB 33090). Serra da Bocaina, Fazenda Bonito, Lutz, A. 528 (R).

Distribution and habitat: Central Brazilian highlands to Paraguay and Argentina (prov. Corrientes). States of Bahia, Mato Grosso, Minas Gerais, Rio de Janeiro, São Paulo, Paraná, Santa Catarina, Rio Grande do Sul. Terrestrial, wet or humid, open places in campo vegetation, alt. 500-1300 m.

The branching morphology of this species is variable. The erect, strobiliferous branches vary from simple to to 3 times forked in the same population. The size of strobili varies, partly in correlation with the number of dichotomies of the strobiliferous branch; a simple one usually has a very large strobilus with ca. 20 rows of sporophylls, whereas the strobili of forked branches usually are smaller and with 12-14 rows. Rarely one of the vegetative branchlets may develop into a new horizontal main branch (Heiner 638, S).

Table 37 in Nessel (1927) is a good illustration of the growth habit of the species.

Hatschbach 29056 (MBM) has a creeping horizontal branch rooting with intervals of $1-3 \mathrm{~cm}$, and has a simple strobiliferous branch, and thus resembles $L$. longipes, however, the lateral branches of the creeping stem are erect and with appressed leaves, so belongs to L. geometra.

Lycopodium alopecuroides L. var. nettoanum Glaziou ex Baker, Handb. fern allies 19. 1887: 19. Type: not designated; a Glaziou collection presumably at $\mathrm{K}$ to be selected. According to the description this is an obviously a synonym of $L$. geometra, but no type was found at $\mathrm{K}$ so far.

Lycopodium alopecuroides L. var. juergensii Rosenst. (Hedwigia 46: 165. 1907). Type: Juergens \& Stier n. L 33, not seen, Rio Grande do Sul, Cruz Alta, probably belongs to L. geometra as indicated by the features mentioned in the protologue to be diagnostic.

The illustrations in Nessel (1955, fig. 79) for var. juergensii show $L$. duseniana.

No valid description of Lycopodium heterocaulon Silveira has been found. Material so annotated by Silveira (P), and by Christ (Silveira 292 P-herb. Christ) belongs to L. geometra.

As indicated by the synonymy above this species has been recognized as a taxon at variety level by several authors, but it is indeed a very distinctive species. We have seen it growing together with Lycopodiella longipes under uniform conditions, maintaining the distinctive features indicated in the key.

Lycopodiella longipes (Grev. \& Hooker) Holub, Fol. Geobot. Phytotax. 26: 93. $1991 . \quad$ Fig. 3 Lycopodium longipes Grev. \& Hook., Bot. Misc. 2: 372. 1831. - Lycopodium alopecuroides L. var. integerrimum Spring, Mém. Acad. Roy. Sci. Belg. 15: 75. 1842. - Lycopodium alopecuroides L. var. longipes (Grev. \& Hook.) Rosenst., Hedwigia 46: 165. 1907. - Type: Brazil, Island of St. Catherine, Macrae s.n (E! holotype, K! isotype).

Lycopodium alopecuroides L. var pseudoreflexum Christ, Bull. Herb. Boiss. ser. 2, 2 (8): 706. 1902. - Type: Glaziou s.n. (P-herb. Christ).

Lycopodium alopecuroides L. var. divaricatum Nessel, Arch. Bot. Est. S. Paulo 1: 425. 1927. - Type: Mendonça 1412, Brazil, Rio de Janeiro, Nova Friburgo, campos turfosos, distantes da cidade [BONN-herb. Nessel 23; (no type material was found in London as cited)]. - Note: Nessel attributed this variety to Rosenstock, who had distributed an exsiccatum [Rio Grande do Sul: Porto Alegre, Cascadas, Stier, in Rosenst., Fil. austrobras. exsicc. 251 (BM, E, M, P, S)] under this name. The name was validly published by Nessel, but based on other specimens, as cited above. 
Lycopodium alopecuroides L. var. rigidum Nessel, Arch. Bot. Est. S. Paulo 1: 425. 1927. Syntypes: Ule s.n., Brazil, Goyas: Imediações da Cachoeira de San Antonio, baixadas humidas (R, not seen); F.C. Hoehne 5161, Brazil, Miguel Burnier, 27/1/921 (SP, lectotype, here selected). - Note: Nessel intended to base this variety on Lycopodium inundatum L. var. rigidum Spring (1838: 167-168), which was not validly published. Further, Spring's material (Brasil, Ackermann, Herb. Martius (M, not seen, BR, a mixed collection containing a fragment of Lycopodium clavatum, and an erect strobiliferous branch of of Lycopodiella longipes) was not cited by Nessel.

Horizontal shoots appressed to the ground, firmly rooted with short intervals, at least to 50 $\mathrm{cm}$ long, unequally branched in the horizontal plane, densely covered on all sides by almost uniform or slightly anisophyllous, somewhat upwardly secund, or spreading to perpendicular leaves, (6-) 10-15 mm wide incl. leaves, 1-3 $\mathrm{mm}$ thick excl. leaves, the stem surface and leaf bases sometimes provided with few to many pluricellular hairs. Leaves of horizontal shoots

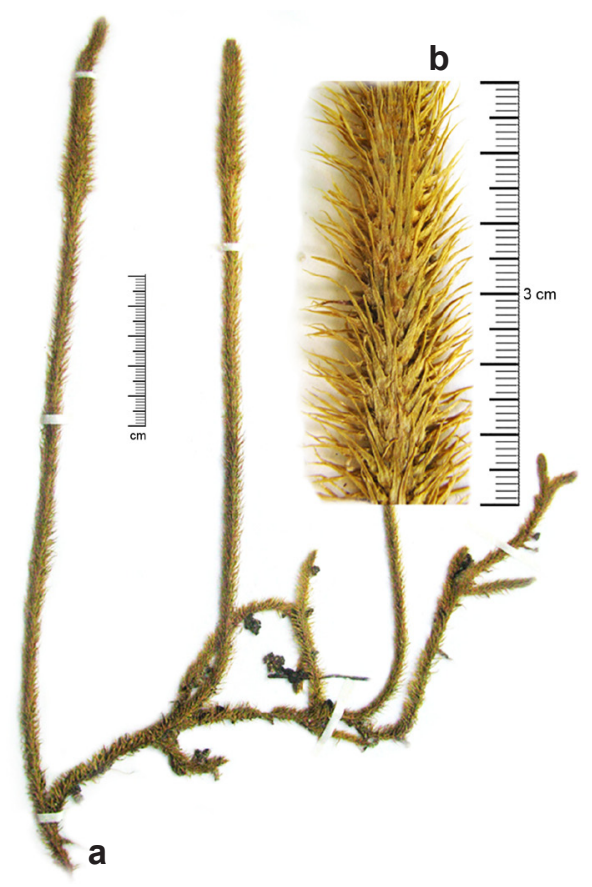

Figure 3-Lycopodiella longipes. Venezuela, Barinas, Altamira - Sto. Domingo, van der Werff \& Ortiz 5861 (AAU). - a. growth habit; b. part of strobilus with sporophylls. narrowly lanceolate or subulate to linear, flat, with smooth to denticulate or long-ciliate margins, soft, light green, 5-7 (-8) × 0.5-1 (-1.2) mm. Ventral leaves of horizontal shoots conform to only half as wide as lateral and dorsal leaves. Erect branches simple or rarely once forked, at least to $45 \mathrm{~cm}$ tall, ca. 4- ca.10 $\mathrm{mm}$ diam. incl. leaves, 1-2 (-2.5) mm thick excl. leaves, its leaves radially arranged, borne in alternating whorls of 6-10, ca. 1.5-3 mm apart, forming 12-20 indistinct longitudinal ranks, essentially like leaves of horizontal shoots, sometimes slightly narrower or with more dentate-ciliate margins, usually ascending to closely appressed. Strobili at least to $16 \mathrm{~cm}$ long, sometimes abruptly forked, 8-15 mm diam. incl. sporophylls. Sporophylls arranged as peduncle leaves, linear-lanceolate to widely lanceolate from a subpeltate base, with few to many, coarse, spreading to hooked teeth on margins, 5-7 (-9) $\times 1-1.5(-2) \mathrm{mm}$. Sporangia ca. $1 \mathrm{~mm}$ diam.

Reference specimens (more than 200 collections studied, complete listing available from the main author): BRAZIL. ACRE: Rio Manso, Linha de Leste, Hoehne 4027, 4028 (R). RONDÔNIA: Savana, Cordeiro 772 (NY). AMAZONAS: Igarapé, Arapopa, Luetzelburg 21596 ( $M, R$ ). PARÁ: Near Santarem, Igarape Irurá, Spruce 350*(K). BAHIA: Nova Viçosa. Restinga, aeroporto de Caravelas. Epigão Mestre, Anderson et al. 36732 (UB). DISTRITO FEDERAL: Brasília, Horto do Guará, Heringer 7860 (HB, UB). ESPIRITO SANTO: Alto Limoeiro. Brade 1.III.1946 (AAU, RB56906). GOIÁS: Chapada dos Veadeiros. 20 Km S of Terezina, 1200 m, Anderson 7449 (UB). MATO GROSSO: Xavantina-Cachimbo, Km 264, Philcox et al. 3086 (K, RB, UB, US). MATO GROSSO DO SUL: Chapadão dos Gaúchos a Vaca Parida, Windisch 4124 (AAU). MINAS GERAIS: (more than 50 collections) Monjolinho-Serra da Ibitipoca, Magalhães 418 (HB). Poços de Caldas, M. Emmerich 2319 (HB). Ouro Preto, Cachoeira das Andorinhas, $1200 \mathrm{~m}$, Mantone et al. 698 (RB). PARANÁ: Desvio Ribas, Dusén 7535 (K, S, US). Palemira, Rodovia do Café, rio Tibi, Hatschbach \& Joly 11270 (MBM). RIO DE JANEIRO: Itatiaia, Serra da Pedra, Dusén 1134 (S, US). Teresópolis, Serra dos Orgãos, Windisch et al. 4981 (AAU). Itatiaia, Lagoa das Prateleiras, Brade 15567 (AAU, S). Restinga de Jacarepaguá, Pedra de Itaúna, Sucre et al. 5371 (AAU). RIO GRANDE DO SUL: Cruz Alta, Stier 32 (S). RORAIMA: Serra dos Surucucus, $1800 \mathrm{~m}$, Prance et al. 9878 (AAU, GH, K, INPA, US). Cimo do Monte Roraima, Terezo (INPA 60509). SANTA CATARINA: Serra da Boa Vista, Rancho Queimado, Reitz 5458), Urubici, Morro da Igreja, Windisch 6042 (AAU). SÃO PAULO: Pico do Jaraguá, Hoehne (SP 5513). Alto da Serra, 750 m, Tryon \& Tryon 6586 (HB). Campos 
da Bocaina, Pabst 4845 (HB). Santo André, Campo Grande, Windisch 144 (GH, HB). Campos do Jordão, Horto Florestal, Windisch et al. 4992 (AAU).

Distribution and habitat: Tropical South America except the Andes south to Argentina (Corrientes), and Uruguay. Brazil: State of Acre, Roraima, Amazonas, Pará, Rondônia, Bahia, Goiás, Distrito Federal, Mato Grosso, Mato Grosso do Sul, Minas Gerais, Espírito Santo, Rio de Janeiro, São Paulo, Paraná, Santa Catarina, Rio Grande do Sul. Open, moist localities on sandy and clayey soil, banks of rivers and roads, brejos, wet grassland, from sea level to $2300 \mathrm{~m}$.

Lycopodiella tupiana (B. Øllg. \& P.G. Windisch) B. Øllg., Rodriguesia 63: 480. 2012. Fig. 4.

Lycopodiella alopecuroides var. tupiana B. Øllg. \& P.G. Windisch, Bradea 5: 30, fig. 4b. 1987. - Type: Brasil: Estado São Paulo, Peruibe (litoral Sul do estado), margem da rod. Pe. Manoel da Nobrega, entre Itanhaem e Peruibe, Km 120, no solo arenoso, juntamente com L. carolinianum, 4 Mar 1972, B. Siegel 6 (HB holotype).

Horizontal shoots appressed to the ground, firmly rooted with short intervals, at least to 40 $\mathrm{cm}$ long, unequally branched in the horizontal plane, densely covered on all sides by almost uniform or slightly anisophyllous, somewhat upwardly secund, or spreading to perpendicular leaves, (6-) 10-15 mm wide incl. leaves, 1-2 mm thick excl. leaves (dried). Leaves of horizontal shoots narrowly lanceolate or subulate, flat, with smooth margins, soft, light green, 5-6 (-8) $\times$ ca. $(0.5-) 1 \mathrm{~mm}$. Ventral leaves of horizontal shoots conform to only half as wide as lateral and dorsal leaves. Erect branches simple, 10-40 cm tall, 3-5 (-8) $\mathrm{mm}$ diam. incl. leaves, 1.5-2 mm thick excl. leaves, its leaves radially arranged, borne in alternating whorls of 5-6 $(-7)$, forming 10-12 (-14) indistinct longitudinal ranks, usually lanceolate, $4-5 \times 0.5-0.8(-1)$ $\mathrm{mm}$, often with dentate-ciliate margins, usually ascending to closely appressed. Strobili to 12 $\times 0.5-1 \mathrm{~cm}$. Sporophylls arranged as peduncle leaves, lanceolate to ovate-long-cuspidate from a subpeltate base, with few to many, coarse, spreading to hooked teeth on margins in the basal half, (3-) 4-5 (-6) mm long at maturity, 1-1.5 mm wide at base. Sporangia ca. $1 \mathrm{~mm}$ diam.

Reference specimens (more than 25 collections studied, complete listing available from the main author): PARANÁ: Jacareí, Dusén 16756 (S), 17491 (NY, S). RIO GRANDE DO SUL: Porto Alegre,
Cascadas, 1906, Stier, in Rosenst., Fil. austrobras. exsicc. 251 (BM, E, K, M, P, S, UC, US). Rio Grande, Malme 125 (S). Cachoeira, 24.II.1893, Lindman, A 1225 (S). Venâncio Aires, Várzea dos Seivaes, 70 m, Jürgens 2 (P, S). Sapiranga, Rambo, B. 41614 (RB). SANTA CATARINA: Araranguá, Sombrio, Smith \& Klein 5869 (US). Araranguá, Arroio Grande, 2.III.1942, Reitz H 135 (GH, RB). Palhoça, Campo do Massiambu, restinga, 5 m, Reitz 4821 (HBR), Ilha de Sta. Catarina, lagoa na areia úmida, Rohr 1084 (RB). Araranguá, Morro dos Conventos, Camargo 3857 (HBR). Içara, Rincão, road to rio Torneros, $20 \mathrm{~m}$, Windisch 4135 (AAU). SÃO PAULO: Guarujá, near Santos, Myndel Pedersen 2572 (BR, C, P, US). São Vicente, in arenosos humidis litoralibus, Mosén 3554 (S). São Vicente, Praia Grande, 11.I.1964, restinga Pereira, E. 8159 (HB). Iguape: Ilha Comprida, Brade 21458 (HB). Itanhaém, Salino 6624 (BHCB).

Distribution and habitat: Endemic to Brazil and Uruguay. This species is ecologically and geographically well characterized, and apparently is restricted to wet or seasonally inundated, grassy campos (coastal plains) dunes and "restinga" formations, at sea level along the coast from the State of São Paulo to Uruguay: São Paulo, Paraná, Santa Catarina, Rio Grande do Sul.

Deviates from Lycopodiella longipes by the generally shorter and wider, entire and often somewhat coriaceous leaves of the horizontal shoot, and in the erect axes by the appressed leaves and sporophylls, and narrow aspect of strobili.

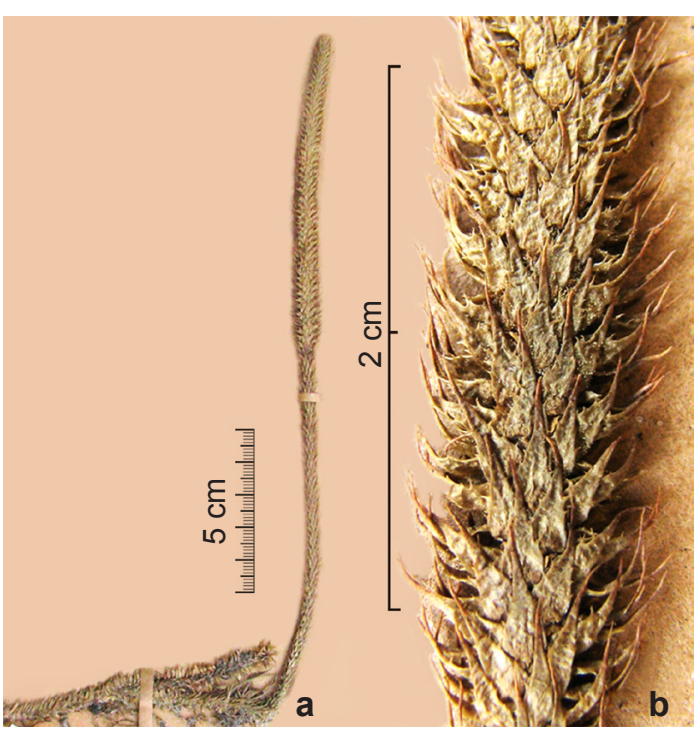

Figure 4 - Lycopodiella tupiana. Brazil, São Paulo, Peruibe, litoral sul do estado, Siegel 6(HB). Holotype. - a. growth habit; b. part of strobilus with sporophylls. 
Palhinhaea Vascon. \& Franco, Bol. Soc. Broter. II, 41: 24. 1967. Type: Palhinhaea cernua (L.) Vasc. \& Franco (=Lycopodium cernuum L.).

Lycopodiella sect. Campylostachys (K. Müller) B. Øllg., Opera Bot. 92: 175. 1987. Lycopodium sect. Campylostachys K. Müller, Bot. Zeit. 19(24): 163. 1861. - Lycopodium subgen. Rhopalostachya Pritzel sect. Cernua Pritzel, Nat. Pflanzenfam. 1(4): 602. 1901, p.p. - Type: Lycopodium cernuum L.

Sporophytes with trailing to arching or looping indeterminate shoots which root with usually long intervals and occasionally branch in the horizontal plane, giving off horizontal branchlet systems, - and usually bearing one main erect branch arising on the dorsal side of every loop; the main erect branch bears a series of subdecussately arranged, spreading to hanging, flabellate branchlet systems, which in turn may terminate in sessile, nodding to pendulous strobili (Palhinhaea bradei is exceptional in lacking an erect aerial branch system, and in the erect, sessile strobili; $P$. steyermarkii is unusual because of the long, slender, scandent, climbing, or creeping main axes, which give off spreading to flaccidly hanging lateral branchlet systems). Leaves and stem surfaces often with short, unicellular or pluricellular and branched hairs; sporangia almost enclosed in cavities formed by the strobilar cortex and the coalescent basal membranes of adjacent sporophylls (Figs. 7; 9; 10), subglobular, anisovalvate. The similar structure for Lateristachys Holub was described by Tardieu-Blot (1970). Sporangium epidermis cells with nodular or buttress-like, lignified thickenings on the side walls; spores rugate to nearly smooth; $\mathrm{n}=104,108$, 110, 136, 156, c.165, 208.

Moist tropics, commonly pioneers on disturbed soil. Palhinhaea cernua is pantropical. Most other species have narrow distributions. 16-20 species in the Neotropics.

Species diversity is especially high on tropical mountains. Palhinhaea steyermarkii may grow as a high-climbing epiphyte. Species diversity seems higher in this group than commonly assumed.

\section{Key to the species of Palhinhaea in Brazil}

1. Plants with erect, tree-like branch systems, (rarely scandent or epiphytic), terminating in nodding to pendulous strobili; sporophyll margins denticulate to erose-denticulate.

1'. Plants small, with creeping, mat-forming shoot systems; strobili ascending to erect, sporophyll margins smooth Palhinhaea bradei

2. Branchlet leaves imbricate, distinctly flattened, lanceolate-ovate, with densely fimbriate margins . Palhinhaea riofrioi

2'. Branchlet leaves spreading to arcuate-appressed, acicular, terete, angular or apically flattened, smooth, or with more or less distant cilia or pointed hairs.

3. Main stems slender, 1-1.5 mm thick, creeping or scandent, not forming robust erect, tree-like aerial shoots, with rather distant, loosely appressed leaves, glabrous; strobili to $9 \mathrm{~cm}$ long 3-4 mm thick, sporophylls $4-5 \mathrm{~mm}$ long.. Palhinhaea steyermarkii

3'. Main stems robust, forming erect, tree-like aerial shoots, usually with crowded arcuateascending leaves, glabrous or hairy, strobili $2.5-3 \mathrm{~mm}$ thick, sporophylls $1-3(-3.5) \mathrm{mm}$ long.

4. Lateral branchlet systems of dendroid erect branch usually stiffly ascending or suberect, often densely aggregated, ultimate branchlets pointing upward, not recurved; strobilusbearing branchlets usually sharply reflexed at tip, or only the strobilus reflexed....

Palhinhaea camporum

4'. Lateral branchlet sytems of the dendroid erect branch patent to ascending, or recurved, the ultimate branchlets usually nodding, or long pendulous and sparsely branched distally.

5. Ultimate branchlets divaricate to somewhat aggregate, patent to horizontal, usually with short-recurved tips; sporophyll margins coarsely erose-laciniate to irregularly dentate; slender to rather robust plants, usually with delicate to almost capillary leaves Palhinhaea cernua

5'. Ultimate branchlets usually long pendulous, sparsely branched, almost parallel; sporophyll margins denticulate to dentate; relatively coarse plants with strongly curved, somewhat leathery leaves Palhinhaea eichleri 
Palhinhaea bradei (Herter) Holub, Folia Geobot. Phytotax. 26: 93. 1991. Figs. 5; 6

Lycopodium bradei Herter, Revista Sudamer. Bot. 8: 21. 1949. - Lycopodiella bradei (Herter) B. Øllg., Opera Bot. 92: 176. 1987. - Type: Minas Gerais: Serra do Caparaó, Lajão, 2500 m, 18. 9. 1941, A.C. Brade 16959 (RB 45817; herb. Herter 61336 (?), AAU isotype).

Lycopodium fastigiatum $\mathrm{R}$. Br. var. schumacheri Nessel, in Hoehne, Fl. Bras. Fasc. 11 (II:II): 119, fig. 106. 1955, nom. nud.

Plants prostrate, forming loosely appressed mats. Main stem to $25 \mathrm{~cm}$ long, rooting with short intervals, creeping, or sometimes underground, 1-2 mm thick excl. leaves, horizontally branched and giving off anisotomous, highly compound, flabellate, creeping to ascending, 2-6 cm long branchlet systems, which in turn may develop into new creeping main stems. Branchlets $3-6 \mathrm{~mm}$ diam. incl. leaves. Branchlet leaves usually borne in densely crowded, alternating low spirals or oblique whorls of 4-6, forming 8-12 obscure longitudinal ranks, $2-3.5 \times 0.3-0.5(-0.7) \mathrm{mm}$, acicular, flattened to terete or angular (dried), with often slightly acroscopically adnate, and long decurrent bases, arcuate-appressed to spreading, loosely to densely crowded, entirely glabrous. Strobili sessile, erect, terminating minor branchlets, $4-7 \times$
2-2.5 mm excl. free sporophyll tips. Sporophylls borne in alternating whorls of 4-6, forming 8-12 longitudinal ranks, with coalescent leaf bases almost enclosing the sporangia, with triangularlanceolate to widely triangular-ovate, short to long cuspidate, $1-1.5 \times 0.5-0.8 \mathrm{~mm}$, with usually strongly upward curved tip, entirely herbaceous, with smooth margins. Sporangia globose, ca. 0.7 mm diam.

Additional collections studied: BRAZIL. MINAS GERAIS: Serra de Caparaó, 1800 m, Schwacke 6260 (RB). Campos do Caparaó, Schwacke (R 18292). Serra do Caparaó, trail to Pico da Bandeira, $41^{\circ} 45^{\prime} \mathrm{W} 20^{\circ} 30^{\prime}$ 'S, 2400-2500 m, Windisch et al. 4962, 4967 (AAU, HB, SP). Caparaó, near Terreirão, 2400 m, Krieger CESJ 24224 (AAU). Alto Caparaó, trail Tronquera-base of Pico da Bandeira, region of Tres Lagoas, in trail to Pico do Cristal. 1800-2560 m, Salino et al. 11431 (photo in AAU ex BHCB). RIO DE JANEIRO: Itatiaia, Agulhas Negras, Campos Porto 1121 (AAU, RB). Itatiaia, Prateleiras, ca. 2200 m, Camerik 190, 191 (U).

Distribution and habitat: Endemic to SE Brazil. In addition to the type locality, Palhinhaea bradei is known from Mount Itatiaia, Agulhas Negras. Alt. 1800-2560 m. We have seen it on the type locality, where it grows on almost bare soil, with mosses, on the banks of the trail leading to Pico da Bandeira, at alt. 2300-2500 m (Fig. 6, habitat photo).

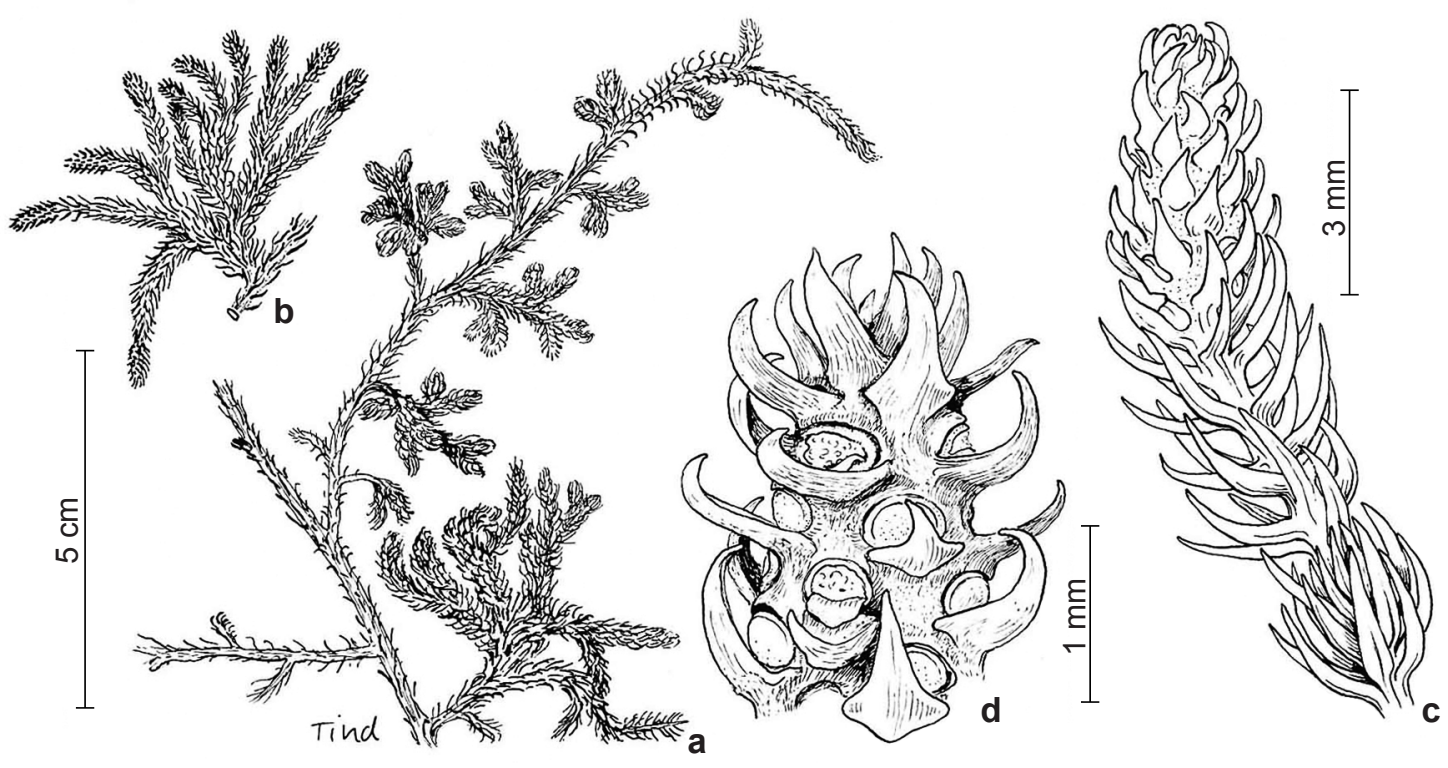

Figure 5 - Palhinhaea bradei. Brazil, Minas Gerais, Serra do Caparaó, Windisch et al. 4967 (AAU). - a. growth habit; b. fertile branchlet system; c. fertile branchlet; d. strobilus showing partly enclosed sporangia. 


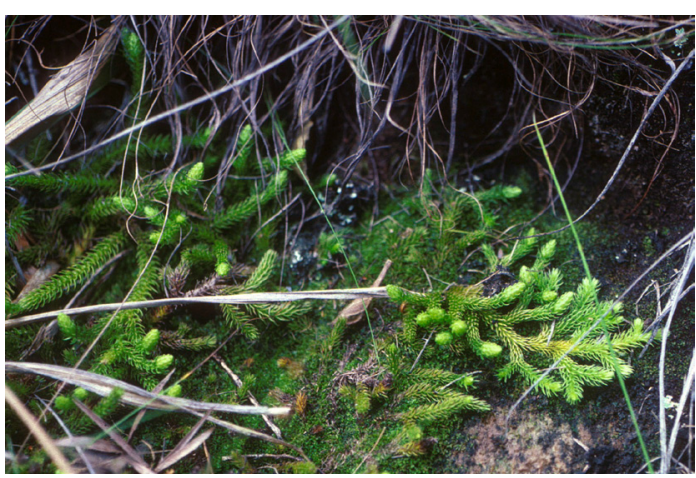

Figure 6 - Palhinhaea bradei. Brazil, Minas Gerais, Serra do Caparaó, Windisch et al. 4967 (AAU). Photo: B. Øllgaard.

This species is unique in Palhinhaea due to the absence of erect, tree-like aerial branch systems. The whole plant is prostrate, forming a flabellate shoot system. The main stems are creeping or occasionally underground. Also the erect strobili are unusual in the genus, in which the strobili are otherwise nodding or pendent. However, its coalescent sporophyll bases, almost enclosing the sporangia, the cell structure of the sporangium wall, and the spore morphology, clearly indicate that it belongs to Palhinhaea. The peculiar morphology made both Nessel and Herter (1. c.) consider it to be a dwarfed relative of Lycopodium fastigiatum (Austrolycopodium).

Palhinhaea camporum (B. Øllg. and Windisch) Holub, Folia Geobot. Phytotax. 26: 93. 1991.

Fig. 7d-f

Lycopodiella camporum B. Øllg. \& P.G. Windisch, Bradea 5: 24, fig. 3. 1987. - Type: Brasil: Est. Minas Gerais: Mun. Santana do Riacho, estrada Lagoa Santa-Conceição do Mato Dentro, Km 113, Serra do Cipó, córrego do Vitalino, alt. 1150 m, campo rupestre, parte alta do barranco do córrego, inundada durante as cheias, 1 Feb. 1987, J. Prado et al. 69 (HB, holotype, AAU, RB, SP, SPF, isotypes).

Illustrations: Nessel (1927) tab. 43 and 44, as Lycopodium cernuum var. eichleri; Nessel (1955) fig. 110 in, as Lycopodium cernuum var. eichleri.

Plants with short to long, arching-looping runner shoots, rooting at soil contact, bearing stiffly erect, dorsally arising, amply branched, to $1 \mathrm{~m}$ tall, tree-like aerial shoots. Erect axes bearing several, subdecussate to alternate, often densely aggregated, stiffly ascending, 5-10 (-20) cm long lateral branchlet systems. Ultimate branchlets 2.5-7 mm diam. incl. leaves, stiffly ascending to erect, only the strobiliferous ones rather sharply recurved at the tip. Branchlet leaves usually borne in densely crowded, alternating low spirals or oblique whorls of 5-7, forming 10-14 longitudinal ranks, 2.5-4 $\times$ ca. $0.3-0.5 \mathrm{~mm}$, acicular, terete or angular (dried), sometimes flattened in the lower half, with often slightly acroscopically adnate and long decurrent leaf bases, patently arcuate-ascending to arcuateappressed, entirely smooth to densely hairy on leaf bases, rarely with soft hairs on leaf margins. Strobili usually numerous, sessile, terminating recurved tips of ultimate branchlets, to $2.5 \mathrm{~cm}$ long, 2-3 mm diam. Sporophylls borne in alternating whorls of 5-7, forming 10-14 longitudinal ranks, with coalescent leaf bases almost enclosing the sporangia, with widely ovate, short to long cuspidate, $1.5-2 \times 0.6-0.9 \mathrm{~mm}$, with scarious, coarsely erose-laciniate margins. Sporangia globose, ca. $0.6 \mathrm{~mm}$ diam., strongly anisovalvate. Reference specimens (more than 120 collections studied, complete listing available from the main author): BRAZIL. AMAZONAS: Serra de Tunui, Caatinga, Black 482886 (RB). Serra Araçá, SE part of Serra Norte, Tavares et al. 71 (K). BAHIA: Rio Corrente drainage, $150 \mathrm{Km} \mathrm{SW}$ of Barreiras, alt. $850 \mathrm{~m}$, Irwin et al. 14770 (GH, K, RB, UB, US). Rio de Contas, Pico das Almas, E slope, 9-11 Km from city, $1120 \mathrm{~m}$, Harley et al. 25919 (AAU). DISTRITO FEDERAL: $15 \mathrm{Km}$ E of Brasília, alt. 700-1000 m, Irwin \& Soderstrom 5740 (K, SP, US). Sobradinho, $1075 \mathrm{~m}, 10 \mathrm{Km}$ E of Brasilia, Irwin et al. 8865 (HB, SP, US). Bacia do Rio São Bartolomeu, Rio Paranoá, 19.III.1981, Heringer, E.P. et al. 6501 (AAU). GOIÁS: Jataí, rio Bom Successo, Hatschbach \& Koczicki 33352 (MBM). Chapada dos Veadeiros, $17 \mathrm{Km} \mathrm{N}$ of Alto Paraiso, $1600 \mathrm{~m}$, Anderson et al. 6607 (K, UB, US). Serra Dourada, $20 \mathrm{Km}$ E of Formoso, Dawson 14837 (US). Serra dos Cristais, S of Cristalina, 1200 m, 3 Irwin et al. 13368 (HB, S, UB, US). Parque Nacional das Emas, Córrego Voador area, $800 \mathrm{~m}$, Guala, 1361 (AAU). Corumbá de Goiás, near Pico dos Pireneus, 1250 m, Irwin et al. 19332 (COL, UB, US). Serra dos Pireneus, $10 \mathrm{Km}$ E of Pirenópolis, $1000 \mathrm{~m}$, Irwin et al. 34172 (UB, US). 2-6 Km N of Miracema do Norte, 29.VII.1964, Prance \& Silva 58469 (COL, S, UB, US). MATO GROSSO: Cuiabá, Chapada dos Guimarães, road to Veu da Noiva, 500-550 m, Windisch 5381 (AAU, SJRP), Barra do Garças, road MT 336 - Barra do Garças-Toricuieje, Km 2 along BR158 to Nova Xavantina, Rio Araguaia, 400 $\mathrm{m}$, Windisch 5828 (AAU, SJRP). Canarana, BR 1582 $\mathrm{Km} \mathrm{N}$ of access road to Canarana, Río Xingu, Windisch 5949 (AAU. SJRP). General Carneiro, Rio Araguaia, 28 $\mathrm{Km}$ from General Carneiro, $450 \mathrm{~m}$, Windisch \& Oliveira 6357 (AAU, SJRP). Near road Xavantina-São Felix road, Km 270, Ratter et al. 1719 (E, K, UB, US). Vila Bela SS Trindade, Serra Ricardo Franco, Windisch 1399 (AAU, 
HRCB). MATO GROSSO DO SUL: Campo GrandeMiranda, Km 50, Windisch 4110 (AAU, SJRP). Campo Grande, Parque de Jatobás, 5.XI.1977, Rodrigues et al. 233 (RB). MINAS GERAIS: Diamantina, Perreira 2772 (HB). Santa Barbara do Mato Dentro, 17.I.1921, Hoehne 5010 (SP). Mariana, Passagem de Mariana, Laboriau 1029 (AAU). Ouro Preto, serra do Itacolumi, Campo, 1100 m, 26.I.1977, Carauta 2285 (HRCB, RB). São João d'El-Rei, Lindman A83 (S). Serra do Cipó, Mun. Jaboticatubas, road Lagoa Santa-Conceição do Mato Dentro-Diamantina, Km 115, 4.III.1972, Joly, A.B. et al. 785 (E, SP). Serra do Espinhaço, $55 \mathrm{Km} \mathrm{E} \mathrm{of} \mathrm{Belo}$ Horizonte, 1550 m, Irwin et. al. 30575 (UB, US). Serra do Ouro Branco, Hoehne 5205 (SP). PARÁ: Obidos, Rio Jaramacarú, Campo do Ariramba, Cavalcanti147
(HB). Serra do Cachimbo, BR 163 (Cuiabá-Santarem) Km 791, 440 m, Prance et al. 25315 (K, US). Itaituba, near Cachimbo air base, Silva et al. 77 (K). PARANÁ: Sengés, Rio do Funil, Hatschbach \& Lange 5280 (MBM, US). RONDÔNIA: Basin of Rio Madeira, AbunãRio Branco, Vilhena, Pires Furtado \& S. Silva 213 (RB). Basin of Rio Madeira, Km 0-6 road Abuña-Rio Branco, before Rio Madeira, 15.VII.1968, Prance et al. 6075 (COL, GH, K, S, US). RORAIMA: Serra dos Surucucus, 1800 m, Prance et al. 9887 (K, US). SÃO PAULO: São Carlos, Rio Monjolinho, 850 m, Eiten et al. 3044 (K, SP, US). Pedro Taques, road CubatãoMonganguá, Mattos 11827 (AAU). Moji-Guaçu: NNW of Pádua Sales, Eiten \& Eiten 1753 (SP). São Paulo, Jaguaré, Gehrt (SP 4154).
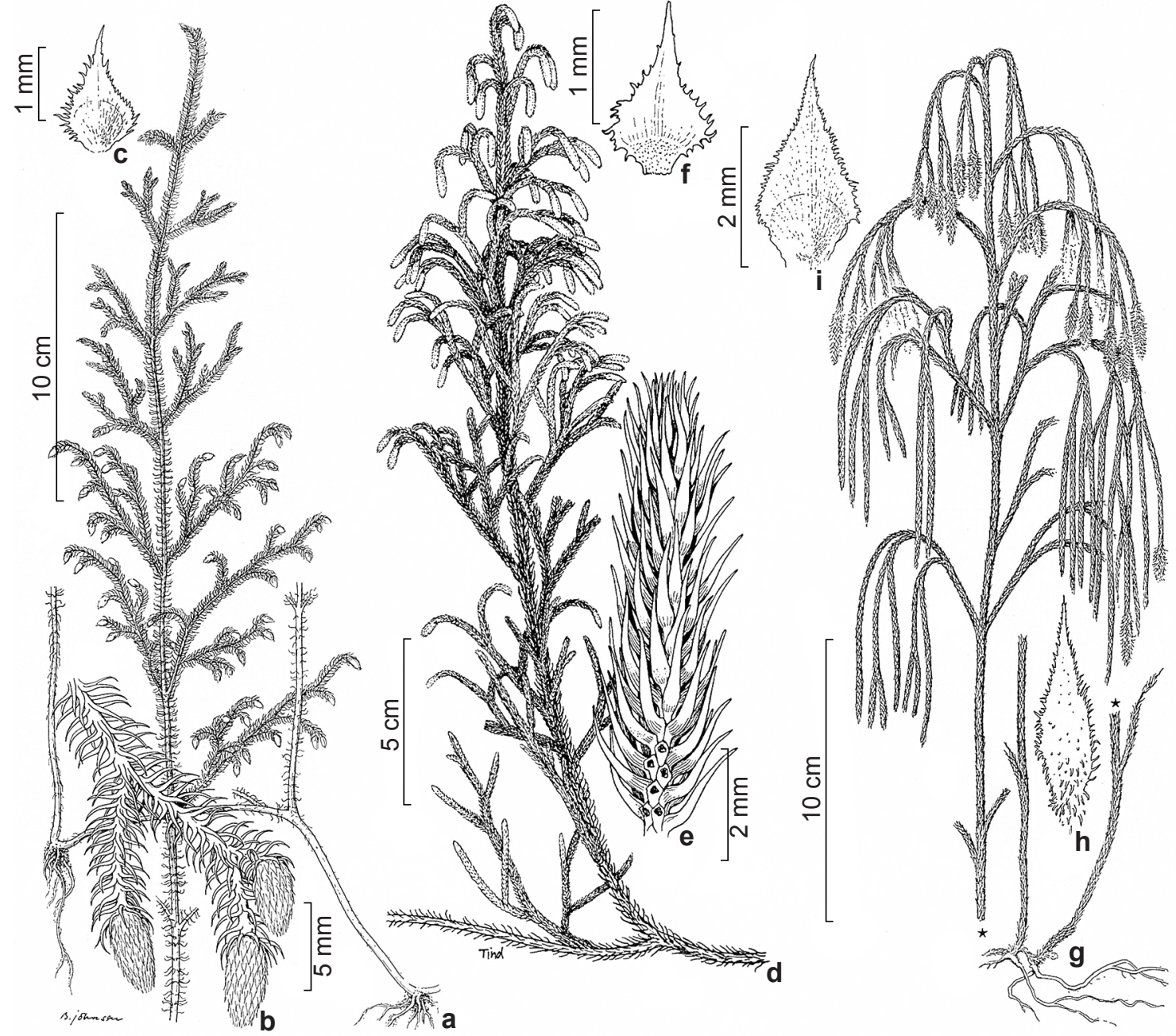

Figure 7 - a-c. Palhinhaea cernua. Ecuador, Holm-Nielsen et al. 4494 (AAU). - a. growth habit; b. fertile branchlets; c. sporophyll. d-f. Palhinhaea camporum. Brazil, Minas Gerais, Serra do Cipó, Prado et al. 69 (AAU Isotype). - d. growth habit; e. ultimate branchlet; f. sporophyll. g-i. Palhinhaea riofrioi. Ecuador, Harling \& Andersson 12811 (AAU). - g. growth habit; h. branchlet leaf; i. sporophyll. 
Distribution and habitat: Amazonian Colombia, Peru, Bolivia, Argentina and Paraguay, savanna region of Venezuela, Guyana and Surinam. States of Roraima, Amazonas, Pará, Rondônia, Mato Grosso, Mato Grosso do Sul, Goiás, Distrito Federal, Bahia, Minas Gerais, São Paulo, Paraná. Swamps, moist campo-grasslands, on peaty or sandy soil, often in the light-open vegetation adjacent to gallery-vegetation at rivers, often subject to flooding during the rainy season; alt. 440-1800 m, most commonly 600-1200 m.

Palhinhaea camporum is a widespread species, which has been confused with Palhinhaea pendulina, $P$. cernua and synonyms thereof. The distinctive branching habit and characteristic ecology makes $P$. camporum a rather easily recognizable and biologically well-defined taxon, although detail characters do not seem strong. It is not rare to find the P. cernua and P. camporum growing together.

Palhinhaea cernua (L.) Vasc. \& Franco, Bol. Soc. Brot. 41: 25 (1967).

Fig. 7a-c

Lycopodium cernuum L., Sp. Pl. 1103 (1753). - Lepidotis cernua (L.) Palisot, Prodr. Aetheogamie 108 (1805). - Lycopodiella cernua (L.) PichiSermolli, Webbia 23: 165 (1968). - Type: LINN 1257.13, selected by Proctor, Flora of the Lesser Antilles, Vol. 2, 1977, 33.

Lycopodium cernuum var. capillaceum Spring, Mém. Acad. roy Belg. 15 (Mon. Lyc. 1): 80 (1842). - Lycopodium capillaceum (Spring) Hieron., Bot. Jahrb. 34: 573 (1905). - Palhinhaea capillacea (Spring) Holub, Folia Geobot. Phytotax. 20: 78. 1985. - Type: Venezuela, Edo. Monagas, Guanaguana, Humboldt 473 (B-Herb. Willd. 19429 holotype).

Lycopdium cernuum L. var. brevifolium Christ ex Hassler, Bull. Herb. Boiss., ser. 2, 3: 620. 1903. - Type: Paraguay: In palude pr. flumen Jejui-Guazu, Hassler 4677 (G).

Lycopodium cernuum L. var. panamense Nessel, Revista Sudamer. Bot. 6: 173, fig. 102, 1940. - Type: Central Panama, Balboa, 1921, Powell s.n. (BONN-Nessel 354).

Plants with long arching-looping runner shoots, rooting at long intervals, bearing erect, dorsally arising, amply branched, to $1 \mathrm{~m}$ tall, tree-like shoots. Erect main axes bearing several, subdecussate to alternate, highly compound, spreading to horizontal, 5-15 (-20) cm long lateral branchlet systems. Ultimate branchlets nodding, 3-4 (-6) mm diam. incl. leaves. Branchlet leaves usually borne in densely crowded, alternating whorls or low spirals of 3-5, forming 6-10 indistinct longitudinal ranks, usually 3-4 $\times$ ca. $0.3 \mathrm{~mm}$, acicular, terete to angular (dried), with often conspicuously acroscopically adnate, and decurrent leaf bases, gradually changing from patent-reflexed and distant on main axes, to patent, upward curved and densely crowded in ultimate branchlets, occasionally with sparse, lax hairs or minute spinules; leaf bases often with longer, irregularly criped or branched hairs, these rarely also on stem surfaces. Strobili usually numerous, sessile, terminating ultimate branchlets, 4-10 $(-20) \times 2.5-3 \mathrm{~mm}$. Sporophylls usually borne in alternating whorls of 5, forming 10 longitudinal ranks, with coalescent leaf-bases almost enclosing the sporangia, with ovate-deltoid, short to long cuspidate, ca. $2 \mathrm{~mm}$ long, ca. $1 \mathrm{~mm}$ wide exterior face, with membranous, coarsely erose-laciniate margins. Sporangia globose, $0.5-0.8 \mathrm{~mm}$ diam., strongly anisovalvate, the epidermis cells with straight, unlignified side walls and buttress-like lignified thickenings. Spores rugate, without a distinct equatorial rim.

Reference specimens (more than 200 collections studied, complete listing available from the main author): BRAZIL. ACRE: Cruzeiro do Sul, Rio Moa at Cachoeira Grande, Prance et al. 12525 (AAU, K, US). AMAPÁ: Serra do Navio, Emmerich 725 (HB). Inselberg Talouakem, Massif de Tumuc-Humac, $650 \mathrm{~m}$, de Granville et al. 12209 (CAY). AMAZONAS: Serra Aracá plateau, SE part of Serra Norte, 1150-1250 m, Tavares et al. $71(\mathrm{~K})$. Manaus, $10 \mathrm{Km}$ de Forquilha, Chagas 106 (HB, US). Manaus, Km 3, Aleixo road, Prance et al. 11537 (AAU, K, US). Río Vaupés, between Ipanoré and confluence with Río Negro, Taraucá, 9 Nov 1947, Schultes \& Pires 9042 (GH). BAHIA: Ilhéus, along road to Itabuna $1 \mathrm{Km} \mathrm{W}$ of Rodoviaria, Edwards 2313 (AAU, K). Serra do Tombador, Rio Ferro Doido, ca. $18 \mathrm{Km} \mathrm{E}$ of Morro do Chapeu, $1100 \mathrm{~m}$, Irwin et al. 32620 (SP, US). Morro do Chapeu-Mundo Novo, $\mathrm{Km}$ 19.5, by the Río Ferro Doido, $900 \mathrm{~m}$, Harley et al. 19260 (AAU, K). CEARÁ: Serra do Baturité, Sta. Clara, Eugenio 53 (AAU). DISTRITO FEDERAL: $30 \mathrm{Km} \mathrm{NE}$ of Brasília, Irwin et al. 15878 (K, UB). Bacia do rio São Bartolomeu, Heringer et al. 6523 (AAU). (AAU). ESPIRITO SANTO: Near Santa Barbara de Caparaó, Mexia 4010 (K, P, US). GOIÁS: Rio Corumbá, road Pires do Rio - Goiás, Heringer 7766 (HB). Cristalina, Road Brasilia - Belo Horizonte, River Topázio Km 92, Oliveira (UB). Serra dos Cristais, $5 \mathrm{Km} \mathrm{S}$ of Cristalina, Irwin et al. 13368 a (HB, SP). Serra dos Pireneus, 12 Km S of Corumbá de Goiás, Irwin et al. 11033 (HB). Chapada dos Veadeiros, 16-17 Km N of Alto Paraiso, Anderson 6607 (AAU). Goiás (Goiás Velho), Serra Dourada, road BR-070 Goiás-Goiânia, Km 10, Windisch 
5931 (AAU, SJRP). MATO GROSSO: Pedra Preta, Serra da Petrovina, BR 364, Windisch 5374 (AAU, SJRP). Alta Floresta, $12 \mathrm{Km}$ from Alta Floresta, Windisch 4802 (AAU, SJRP). Marcelândia/Itauba, road to Marcelândia, Rio Manissauá-Miçu, Km 61 on BR 163, 300-350 $\mathrm{m}$, Windisch \& Oliveira 6424 (AAU, SJRP). MINAS GERAIS: Ouro Fino, Hoehne 19405 (SP). Ouro Preto, Campo, 1000 m, Ferreira 7763 (PAMG). Ouro Preto, road to Pico do Itacolumi, Windisch et al. 4952 (AAU). Camanducaia, Vila Monte Verde, Serra da Mantiqueira, 5899 (AAU, SJRP). Serra do Espinaço, at Lapinha, 21 $\mathrm{Km} \mathrm{N}$ of Serro on road to Diamantina, Irwin et al. 20877 (K, SP, UB, US). Lagoa Santa, 1.IX.1863, Warming, E. (AAU). PARÁ: Anapú, Rio Tapacú, Portel, Froes 32778 (HB). Itaituba, road Santarém-Cuiabá, BR 163, Km 1115, Amaral 799. PIAUI: Piracuraca, Carauta 3658 (AAU). PARANÁ: Curitiba, Dombrowski 273 (US). Jacaré́, Dusén 15464 (BR, S). Ponta Grossa, lugar úmido, Brade 19724 (AAU, HB). Jaguaraiva, Estrada do Sertão, Entrada Grande, Hatschbach 11954 (MBM). Paranaguá, Pontal do Sul, Hatschbach 11297 (HB, MBM). PERNAMBUCO: Camorim de São Felix-Agrestina, Radambrasil 205858 (AAU). RIO DE JANEIRO: Corcovado, Dusén 182 (US). Gavea, Hoehne 24624 (SP). Tijuca, road to Vista Chinesa, Lanna Sobrinho 1185 (AAU). Itatiaia, Riberão Campo Belo, above Maromba, Tryon \& Tryon 6664 (HB). Macaé, Serra do Frade, Carauta 1201 (HRCB). RIO GRANDE DO SUL: São Sebastião do Caí, Rambo. 42601 (BR, P, PACA). Capão do Leão-Pelotas, Sacco 1328 (HB). RONDÔNIA: Estrada de Ferro Madeira Mamoré, 10.IX.1923, Kuhlmann 415 (RB). RORAIMA: Serra dos Surucucus, $1800 \mathrm{~m}$, Prance et al. 9887 (M, VEN). SANTA CATARINA: Ilha de Santa Catarina, Pântano do Sul, Klein et al. 6706 (HBR). Pilões, Palhoça, Reitz \& Klein 2477, 2962 (US). Azambuja, Brusque, 7.VIII.1953, Reitz \& Klein 887 (HB, US). Urubici-Tubarão, descent from Grão Pará, 400 m, Windisch 6047 (AAU, SJRP). Timbé do Sul, Serra da Rocinha (Serra dos Pinheiros), 15.2 Km from Timbé, Windisch 6056 (AAU, SJRP). SÃO PAULO: Apiaí, road Iporanga-Apiaí, Alto da Serra, Windisch 6084 (AAU, SJRP). $10 \mathrm{Km} \mathrm{W}$ of Bragança Paulista, 22.VI.1960, Eiten 2026 (SP, US). S José do Barreiro, Hoehne 17687 (SP). Salesópolis, Est. Biológica de Boracéia, Mattos 12444 (AAU). Guarujá, near Santos, Pedersen 2571 (BR, US). Serra da Cantareira, Kocinski 331 (SP). Sorocaba, Presidente Prudente, Strang 1152 (HB). Old road S. Paulo-Santos, 14.X.1961, Pabst 5800 (HB). Santo André, Alto da Serra, Wacket 5 (UC).

Distribution and habitat: Pantropic. Probably present in all the states of Brazil. A common pioneer species throughout the humid regions of the country, on road cuts and moist disturbed soil, along rivers, in forest clearings etc., from sea level to $2200 \mathrm{~m}$ alt.

A variable taxon. Nessel (1927, 1955), recognized a number of varieties, but we are unable to apply these. When Palhinhaea cernua grows in open, exposed habitats it has the typical growth habit with stiffly erect, tree-like aerial shoots; however, in shaded, moist habitats the aerial shoots may branch profusely, and may grow to more than $2 \mathrm{~m}$ long, becoming gradually overhanging or subscandent.

Palhinhaea eichleri (Fée) Holub, Fol. Geobot. Phytotax. 20: 78. $1985 . \quad$ Fig. 8 Lycopodium eichleri Fée, Crypt. Vasc. Brésil II: 96, t. 106, f. 4. 1872-1873. - Lycopodium cernuum L. var. eichleri (Fée) Nessel, Arch. Bot. Est. S. Paulo 1: 446. 1927. - Lycopodiella eichleri (Fée) B. Øllg., Opera Bot. 92: 176. 1987. - Type: Brasilia fluminensi, Alto-Macahe, 1600 m, Glaziou 4478 (P! holotype, $\mathrm{C}$ ! isotypes).

Illustrations: Nessel in Hoehne, Fl. Bras. fasc. 11 (II:II): fig. 111. 1955, as Lycopodium cernuum var. eichleri.

Dendroid branch systems to ca. $40 \mathrm{~cm}$ tall, amply branched, with sparsely to profusely subequally branched, to $12(-20) \mathrm{cm}$ long, usually long pendulous lateral branchlet systems. Leaves of main axes loosely appressed, upward curved, 5-7 × 0.5-1 mm. Ultimate branchlets (3-) 5-6 (-9) $\mathrm{mm}$ diam. incl. leaves, rarely tapering to $2 \mathrm{~mm}$ diam. Branchlet leaves borne in densely crowded alternating whorls or low spirals of 5-7, forming 10-14 indistinct longitudinal ranks, acicular, terete to quadrangular (dried), or sometimes apically flattened, (3-) 4-6 × 0.5-1 $\mathrm{mm}$, patent-ascending, upward curved, softly to firmly herbaceous, glabrous, or with few marginal cilia. Leaf bases and stem surfaces usually with sparse to dense short crisped hairs. Strobili 10-20 $\times 5-6 \mathrm{~mm}$. Sporophylls borne in alternating whorls of 5-6, forming 10-12 longitudinal ranks, (2.5-) 3-3.5 $\times$ ca. $1.5 \mathrm{~mm}$, with lanceolate-ovate, short acuminate exterior face, with irregularly dentate, very narrowly membranous margins, greenish, of herbaceous texture throughout. Sporangia ca. $1 \mathrm{~mm}$ diam.

Collections studied: BRAZIL. MINAS GERAIS: Ouro Preto, road to Cachoeira das Andorinhas, alt. $1300 \mathrm{~m}$, Windisch et al. 4959A, 4960 (AAU). Serra de Ouro Preto, Damazio 1149 (P). Lima Duarte, Parque Estadual Ibitipoca, trail to Janela do Céu, Almeida et al. 1227 (BHCB). RIO DE JANEIRO: Alto Macahé, alt. 1600 m, Glaziou 4478 (C, P). Itaipava-Teresópolis, alt. 900 m, Pabst et al. 7148 (GH, HB, M, VEN). Serra do Mar, access road to Serra da Bocaina, Windisch et al. 5009 (AAU, HB, SP). "Sommet du Tinguá, au plus haut pic", Glaziou 9067 (P). 


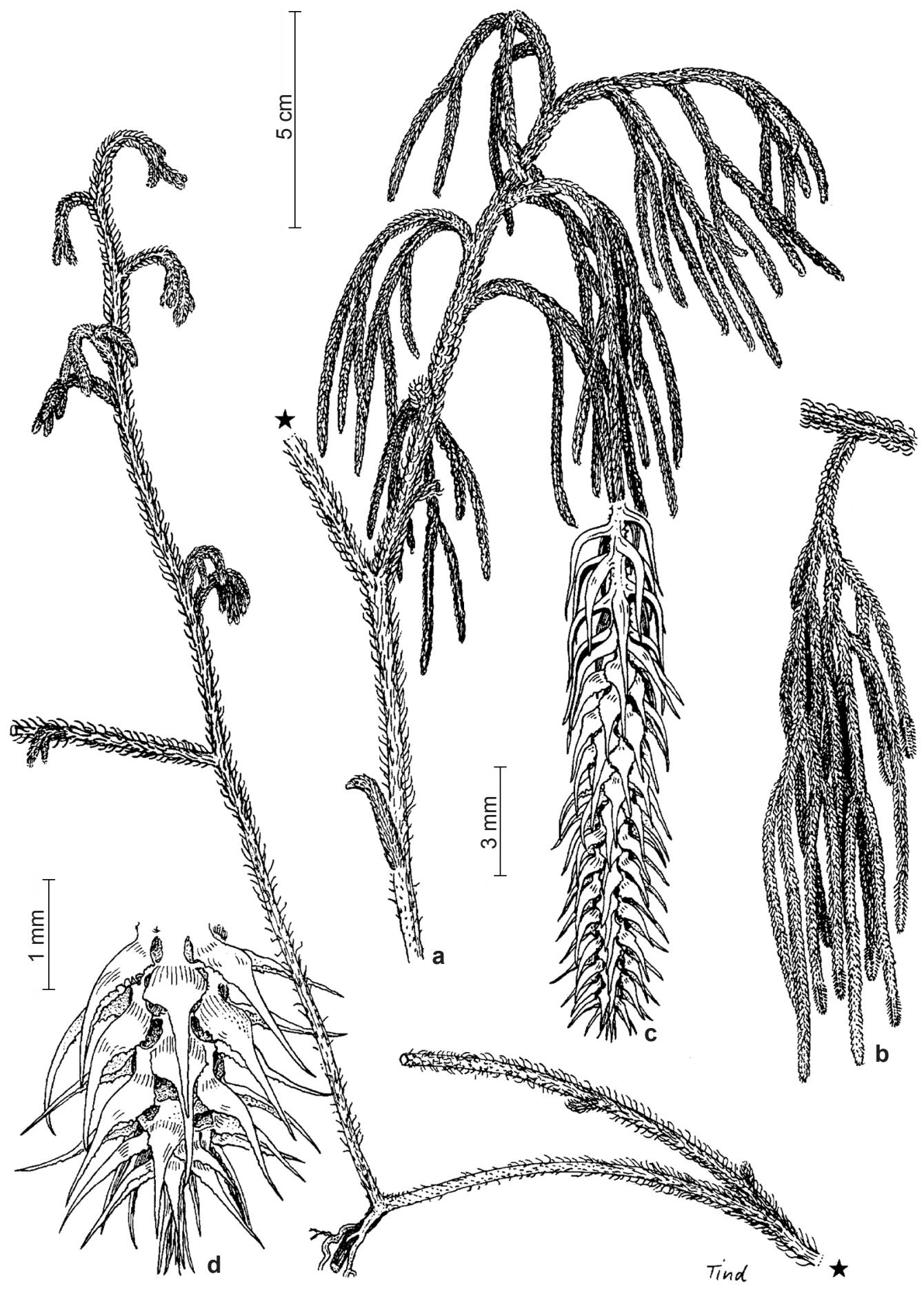

Figure 8 - Palhinhaea eichleri. Brazil, São Paulo, Serra do Mar, Cunha-Paraty, Windisch et al. 5009 (AAU). - a. growth habit; b. branchlet system; c. strobilus; d. strobilus, enlarged. 
Distribution and habitat: Brazil: States of Minas Gerais, Rio de Janeiro. Open sites in cloud forest, alt. 900-1600 m.

Nessel's illustrations (1927, tab. 43-44; 1955, fig. 110) indicated to be Lycopodium cernuum var. eichleri and var. "pendulum Hook." respectively, are of Palhinhaea camporum, and not the present species.

Palhinhaea eichleri is possibly related to $P$. pendulina (Hook.) B. Øllg. (Costa Rica to northern Andes), to which it was referred by Øllgaard \& Windisch (1987). However, it differs in the ultimate hanging branchlets being slender and tapering, and the stem surfaces and leaf bases densely hairy. The material from the vicinity of Ouro Preto seems to represent a slender form of the species. We have seen $P$. eichleri growing together with $P$. cernua on open road banks in Serra da Bocaina. The differences of growth habit and general dimensions are obvious under such circumstances. However we have also seen numerous intermediate individuals and undecisive with respect to their possible hybrid origin. The intermediate individuals appear to have normally developed spores.

Palhinhaea riofrioi (Sodiro) Holub, Fol. Geobot. Phytotax. 26: 93. 1991.

Fig. 7g-i

Lycopodium riofrioi Sodiro, Anal. Univ. Quito 12: 395 (1895) [Crypt. vasc. quitens. 582 (1893)]. Lycopodiella riofrioi (Sodiro) B. Øllg., Opera Bot. 92: 176 (1987). - Type: Ecuador, In silv. occid. m. Pichincha ad Gualea, 9/888, Sodiro s.n. (SI 21230 holotype!).

Lycopodium pensum Lellinger \& Mickel ex Lellinger, Proc. Biol. Soc. Washington 89: 717, fig. 2 (1977). - Type: Costa Rica, prov. Heredia, 6 mi. from San Rafael de Heredia on slopes of Volcán Barba (Cerro Chompipe), McAlpin 216 (DUKE holotype n.v.; GH isotype!).

Illustrations: Lellinger, Proc. Biol. Soc. Washington 89: 717, fig. 2 (1977) as Lycopodium pensum.

Plants with very short to long, arching-looping runner shoots, rooting at soil contact, these bearing dorsally arising, erect, to $2 \mathrm{~m}$ tall, tree-like branched shoots. Erect shoots with several subdecussate to alternate, 10-25 cm long, subequally branched, ultimately long pendulous lateral branchlet systems. Ultimate branchlets $2-3 \mathrm{~mm}$ diam. incl. leaves. Branchlet leaves imbricate, densely crowded, borne in alternating whorls of 4-6, these $1-1.5 \mathrm{~mm}$ apart, forming 8-12 longitudinal ranks, lanceolate to ovate-lanceolate, acuminate, $2.5-4 \times$ ca. $1 \mathrm{~mm}$ wide, with densely ciliate-fimbriate margins, with a very short, patent, terete-subangular base. Stems and leaf bases densely hairy. Strobili sessile, terminating ultimate branchlets, $10-25 \times 3-5 \mathrm{~mm}$ diam. incl. sporophylls. Sporophylls borne in alternating whorls of 5, forming 10 longitudinal ranks, with coalescent bases, almost enclosing the sporangia, ca. $2.5 \times$ ca. $1 \mathrm{~mm}$, with deltoid, short acuminate exterior face, with narrowly membranous, erose-laciniate margins. Sporangia $0.7-1 \mathrm{~mm}$ diam. Spores rugate, without a distinct equatorial rim.

Collections studied: BRAZIL. AMAZONAS: Santa Isabel do Rio Negro, $0^{\circ} 00^{\prime} \mathrm{N} 65^{\circ} 00^{\prime} \mathrm{W}$, P.N. do Pico da Neblina, trail to Anta waterfall, between camp Lajero and Marco 5 of frontier Brazil/Venezuela, cloud forest ascending to Serra da Neblina, Carvalho et al. 370 (INPA). RORAIMA: Frontier between Territory Rio Branco, Brazil, and Estado Bolívar, Venezuela, Serra do Sol, alt. 2100 m, Maguire 40399 (COL, F p.p., NY; - the other part the collection at $\mathrm{F}$ may be a hybrid with Palhinhaea cernua).

Distribution: Costa Rica, Panama, Venezuela and adjacent Brazil, Colombia, Ecuador.

The putative hybrid Palhinhaea cernua $\mathrm{x}$ riofrioi is known from Cerro Neblina (e.g., Beitel 85194, AAU), the Chimantá Massif (Steyermark \& Wurdack 842, AAU, VEN), Meseta de Jaua (Steyermark et al. 109548, US, VEN), Auyan-tepui (Cardona 2645, US, VEN), and Mount Roraima (Steyermark 58935, F, US). Also in Panama. It is distinguished from both of its parents by more vigorous growth. The leaves are wider, coarser and more hairy than in P. cernua, and the leaves of the main axes are usually appressed, and all axes more hairy.

Palhinhaea steyermarkii (B. Øllg.) Holub, Fol. Geobot. Phytotax. 26: 93 (1991). Fig. 9

Lycopodiella steyermarkii B. Øllg., in Harling \& Andersson, Fl. Ecuador 33: 149 (1988). - Type: Ecuador: Prov. Napo: Road Baeza-Tena, ca. Km 23, ca. $2000 \mathrm{~m}$, Øllgaard et al. 35959 (AAU holotype, QCA isotype).

Illustrations: Nessels's illustration (Bärlappgewächse 313, Abb. 72. 1939) of Lycopodium sprucei Baker is Palhinhaea steyermarkii, shown upside down.

Plants with long, slender, scandent, climbing, or creeping main axes, which give off lateral branchlet systems of spreading to flaccidly hanging, at least to $30 \mathrm{~cm}$ long branchlets. Main axes 1-1.5 $\mathrm{mm}$ thick excl. leaves, glabrous. Ultimate branchlets incl. leaves 4-5 $\mathrm{mm}$ diam. Leaves of main axes distant, borne in drawn-out spirals or very irregular 


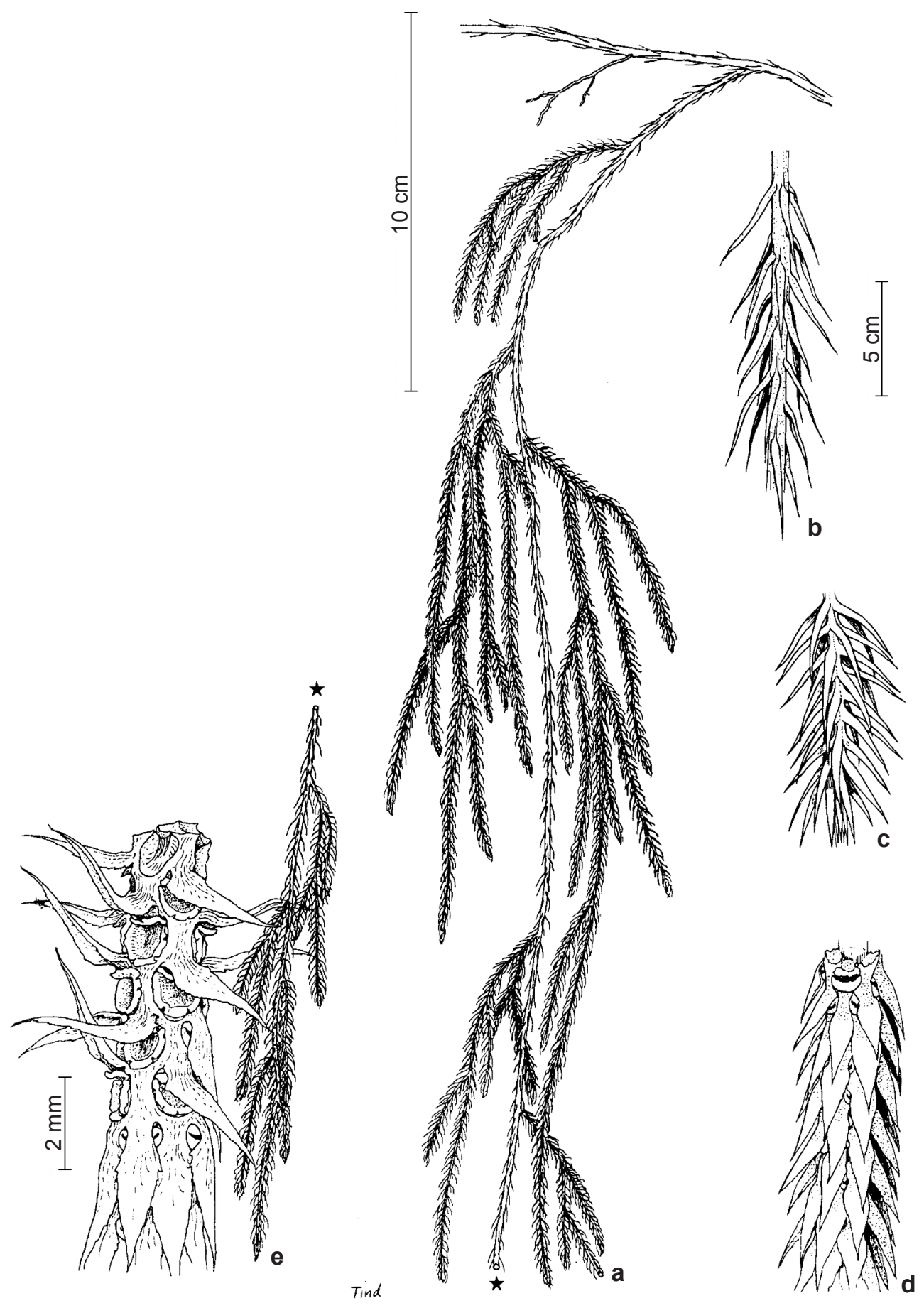

Figure 9 - Palhinhaea steyermarkii. Ecuador, Øllgaard et al. 35959 (AAU). - a. growth habit; b. major branchlet; c. terminal branchlet; d. part of strobilus; e. part of strobilus showing partly enclosed sporangia. 
whorls, 8-12 seriate, acicular, semiterete to flattened, soft, with a long, slender tip, arcuate-ascending to appressed, 4-6 mm long, glabrous. Branchlet leaves softly to firmly herbaceous, arcuate-ascending to arcuate-appressed, 3-5 × ca. $0.5 \mathrm{~mm}$, evenly tapering from the base, otherwise conform. Strobili to $9 \mathrm{~cm}$ long, ca. $4 \mathrm{~mm}$ thick (with appressed sporophylls). Sporophylls borne in alternating whorls of 4 , forming 8 longitudinal ranks, with coalescent sporophyll bases almost enclosing the sporangia, with lanceolate to lanceolate-ovate, 4-5 × 1-1.5 mm, with shallowly erose-denticulate margins, of herbaceous, green texture throughout. Sporangia globose, 1-1.2 mm diam.

Collections studied: BRAZIL. RORAIMA: Roraima, am Felsenabhang, Dec 1909, 2300 m, Ule 8496 (BONNNessel 201, K, L, Museo Goeldi photo). Roraima, Ule 8416 (BONN-Nessel 200).

Distribution and habitat: Panama, Venezuelan Guayana, Guyana-Venezuela border, Colombia, Ecuador. In Brazil this species is known only from the State of Roraima. Terrestrial or epiphytic in pluvial montane forest, 1900-2200 m. Guayana: Terrestrial, scrambling or creeping, with pendent branchlets, on shaded stream banks, sandstone escarpments, and moist bluffs, 1600-2300 m.

This is the only species in the genus known to grow as an epiphyte. In Venezuela it is mainly terrestrial.

The strobili are remarkably long for this section of the genus. They apparently remain meristematically active for a prolonged period, often having wilted and rotten sporophylls and sporangia at the stobilus base, and at the same time a fresh, actively developing strobilus apex

Pseudolycopodiella Holub, Folia Geobot. Phytotax. 18: 441. 1983. - Type: Pseudolycopodiella caroliniana (L.) Holub (= Lycopodium carolinianum L.).
Lycopodium sect. Caroliniana Bruce, Amer. Fern J. 66: 136. 1976. - Lycopodiella sect. Caroliniana (Bruce) B. Øllg., Opera Bot. 92: 174. 1987. - Type: Lycopodium carolinianum L.

Sporophytes with prostrate, rooting, indeterminate, isophyllous to strongly anisophyllous, horizontally branching shoots, and dorsally arising, erect, simple strobiliferous branches; leaves of strobiliferous branches conform to leaves of prostrate shoots or strongly reduced and distant; sporophylls arranged in alternating whorls of 3-5, rarely decussate, forming 4-10 (-12) longitudinal ranks, free, not enclosing the sporangia at maturity, without veinal mucilage canals; sporangia isovalvate, reniform, widely attached to the sporophyll stalk: sporangium epidermis cells with incompletely lignified or incompletely semiannular thickenings; $\mathrm{n}=35,70,2 \mathrm{n}=115$ (Bruce 1976c), $\mathrm{n}=68$ (Takamiya \& Kurita 1983), $\mathrm{n}=$ c. 69 (Walker 1966).

Tropical and temperate regions, western temperate Asia, Australia, and western temperate North America, absent from Europe. Most species grow on moist or boggy, sandy soil. Some species are adapted to seasonal drought and fire, and may survive such periods by means of subterranean, tuberous stem apices (Kornas 1975). Four to ten rather poorly understood species, with the highest diversity and the primitive, isophyllous species in South America and Australia to New Caledonia (Pseudolycopodiella serpentina). A thick spongy cortex in the prostrate shoots seems to have developed independently as an adaptation to marshy or shallowly inundated growth conditions in species in Southern Africa, Brazil and the Guiana Highlands. Ballard (1950) studied the variability of the African species. Bruce (1976c) gave a detailed account of the morphology of the type species.

\section{Key to the species of Pseudolycopodiella in Brazil}

1. Creeping shoots anisophyllous

2. Creeping stems terete, not fleshy or spongy; the upper side not wide or flattened, dorsal leaves closely spaced

3. Creeping shoots more than $7 \mathrm{~mm}$ wide, with lanceolate to subulate, $3-7 \mathrm{~mm}$ long lateral leaves; dorsal leaves widely lanceolate to subulate

Pseudolycopodiella meridionalis

3'. Creeping shoots to $6(-7) \mathrm{mm}$ wide, with dimidiate to triangular-ovate or widely lanceolate, 2-3 mm long lateral leaves; dorsal leaves widely ovate to ovate-acuminate

Pseudolycopodiella paradoxa

2'. Creeping stems fleshy or spongy, the upper side wide and flattened 
4. Dorsal leaves with approximate, clearly delimited leaf bases, scale-like, covering the dorsal side of the stem. Pseudolycopodiella squamata

4'. Dorsal leaves with distant leaf bases, the stem surface much exposed, narrow leaves rarely present on ventral side of the stem. Pseudolycopodiella carnosa

1'. Creeping shoots entirely isophyllous

5. Creeping stems fleshy and spongy, the upper side somewhat flattened

\section{Pseudolycopodiella tatei}

5'. Creeping stems stems terete, not fleshy or spongy

6. Vegetative leaves of erect, strobiliferous branch densely crowded, strongly upward curved from an almost perpendicular, terete to angular leaf base; strobiliferous branch incl. leaves appearing as thick as, or thicker than the strobilus Pseudolycopodiella contexta

6'. Vegetative leaves of strobiliferous branch distant or subdistant, their bases flattened and appressed, often with slightly recurved tips; strobili appearing thicker than vegetative strobiliferous branch incl. leaves. .Pseudolycopodiella iuliformis

Pseudolycopodiella carnosa (Silveira) Holub, Folia Geobot. Phytotax. 20: 79. 1985.

Fig. 10g-i

Lycopodium carnosum Silveira, Bol. Comm. Geogr. Geol. Minas Geraes 2, 5: 119, t. 7-8. 1898. - Lycopodium carolinianum L. var. carnosum, (Silveira) Nessel, Arch. Bot. Est. S. Paulo 1: 433. 1927. - Lycopodiella carnosa (Silveira) B. Øllg., Opera Bot. 92: 176. 1987. - Types: In humidis prope Fazenda da Mandioca inter Diogo et S. Farncisco da Onça, in vicinia urbis S. João d'El-Rei, Apr. 1894, - et in humidis prope Curral Novo, in via versus Estação de João Ayres, Jun. 1894 et Jun. 1898: Silveira; no. 243 in herb. Com. Geog. et Geolog. civitatis Minas Geraes. (P).

Lycopodium goyazense Underw. \& Lloyd, Bull. Torrey Bot. Club 33: 121. 1906. - Lycopodium carolinianum L. var. goyazense (Underw. \& Lloyd) Nessel, Arch. Bot. Est. S. Paulo 1: 432. 1927. - Pseudolycopodiella goyazensis (Underw. \& Lloyd) Holub, Folia Geobot. Phytotax. 18: 442. 1983. - Type: Brazil: Goyaz: Glaziou 22644 (NY holotype; $\mathrm{P}$, isotypes).

Terrestrial, with short, fleshy, horizontal stems creeping and firmly rooted throughout, bearing one to few, dorsally arising, stiffly erect, simple, strobilus-bearing branches (peduncles). Creeping shoots to ca. $20 \mathrm{~cm}$ long, sparsely and unequally branched, 7-15 $\mathrm{mm}$ wide incl. leaves, strongly anisophyllous, with large and wide lateral leaves, and short, narrow and often rudimentary dorsal leaves, the fleshy, more or less naked-appearing stem surface $2-5 \mathrm{~mm}$ wide excl. lateral leaves. Lateral leaves 3-8 $\times 1.5-3.5$ $\mathrm{mm}$, usually widely triangular-lanceolate and somewhat falcately recurved, flat, with smooth, underlying acroscopic margins and short to long decurrent basiscopic margins, varying from widely triangular to linear-lanceolate (sometimes in the same individual); dorsal leaves relatively distant, arranged in 1-3 (-4) longitudinal ranks (often on the same individual), awl-shaped to subulate, or rarely ovate-acuminate, often rudimentary, appressed to reflexed from a diverging to almost perpendicular base, $1-2(-3) \times$ ca. $1(-1.5) \mathrm{mm}$. Peduncle to $40 \mathrm{~cm}$ tall incl. the strobilus, $1-2 \mathrm{~mm}$ thick excl. leaves, terete, bearing small (ca 3-5 $\mathrm{mm}$ long) subulate leaves in remote, alternating, irregular whorls of 4-6. Strobili to $15 \mathrm{~cm}$ long, ca. 4-8 $\mathrm{mm}$ thick with appressed sporophylls, ca. 8-12 mm thick including spreading sporophylls. Sporophylls borne in alternating whorls of 4-6, forming 8-12 longitudinal ranks, subpeltate, with a thin, median, basiscopic, decurrent wing on the stalk, with a widely ovate-rhombic to widely lanceolate, acuminate, exterior face, 4-7 $\times$ ca. 2-2.5 mm, with minutely fimbriate-denticulate margins. Sporangia reniform, isovalvate, borne on the sporophyll stalk, ca. 1.5-2 mm wide.

Reference specimens (more than 200 collections studied, complete listing available from the main author): BRAZIL. BAHIA: Espigão Mestre, ca. $100 \mathrm{Km} \mathrm{WSW}$ of Barreiras, 750 m, Anderson et al. 36813 (F, GH, UC, US). Drainage of the Rio Corrente, Rio Piau, ca. $150 \mathrm{Km} \mathrm{SW}$ of Barreiras, $850 \mathrm{~m}$, Irwin et al. 14760 (F, US). DISTRITO FEDERAL: Fazenda Água Limpa, near Olho de Água da Onça, Univ. Brasília field station, near Vargem Bonita, Ratter \& Fonseca 2810 (UB). Sobradinho, Granja Ruy Malta, Pires et al. 9349 (HB, UB, US). Lago Paranoá, Cabeça do Veado, Heringer et al. 7391 (AAU). GOIÁS: Chapada dos Veadeiros, ca. $22 \mathrm{Km} \mathrm{N}$ of Alto do Paraiso, 

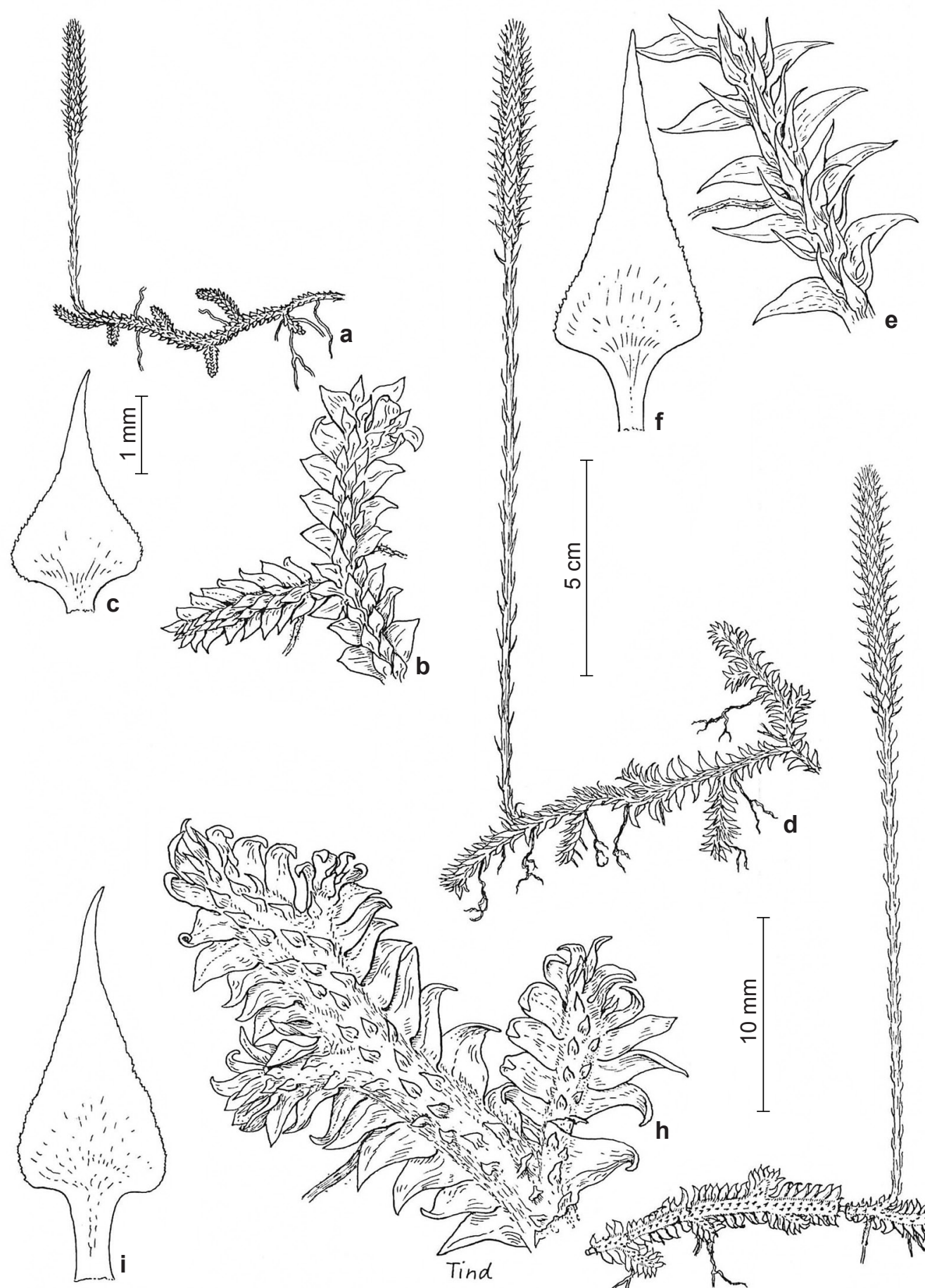

Figure 10 - a-c. Pseudolycopodiella paradoxa. Brazil, Minas Gerais, São João d'El-Rei, Lindman A-81 (S). - a. growth habit; b. prostrate shoot; c. sporophyll. d-f. Pseudolycopodiella meridionalis. Brazil, Paraná, Jacarehy, Dusén 17492 (S) Del. K. Tind. - d. growth habit; e. prostrate shoot; f. sporophyll. g-i. Pseudolycopodiella carnosa. Brazil, Minas Gerais, Caldas, Mosén 4582 (S). - g. growth habit; h. prostrate shoot; i. sporophyll. 
Irwin et al. 32957 (F, UB, US, VEN). Serra dos Pireneus, ca. $21 \mathrm{Km}$ E of Pirenópolis, Irwin et al. 34546 (UB). Saia Velha, Heringer 8132/326 (HB, UB). MATO GROSSO: Cuiabá, Chapada dos Guimarães, Windisch 5378 (AAU, SJRP). 5 Km S of Xavantina, 52²0'W 1444'S, 500 m, Ratter, \& Ramos 512 (E). Água Boa, road CanaranaParanatinga, Rio Xingu, $65 \mathrm{Km}$ from Canarana, 350-400 $\mathrm{m}$, Windisch 5878 (AAU, SJRP). Alto Araguaia, road Alto Araguaia-Alto Taquari, Km 16, Serra do Torto, 500-600 m, Windisch 5360, 5364 (AAU). Barra do Garças, Rio Araguaia, base of Serra Azul, road Barra do Garça-Nova Xavantina, Km 76-77, 350-400 m, Windisch 5838 (AAU). MATO GROSSO DO SUL: Road Campo Grande a Miranda, $50 \mathrm{Km}$ after Campo Grande, Windisch 4112 (AAU, SJRP). MINAS GERAIS: Santa Barbara, Caraça, Mello Barreto 5393 (GH). Caldas, Regnell III 1499 (S, US). Ouro Preto, Saramenha, Macedo 2877 (MO, S). Serra do Cipó, $112 \mathrm{Km}$ N of Belo Horizonte, Glassman \& Gomes 8088 (F). Serra do Espinhaço, slopes of Serra da Caraça, ca. $10 \mathrm{Km} \mathrm{W}$ of Barão de Cocais, Irwin et al. 28866 (F, UB, US). Cachoeira do Campo, Schwacke 12002 (RB). Carandaí, Hermilo Alves, Duarte 6353 (HB). PARANÁ: Imbituva, Rio Imbituvinha, Hatschbach \& Ravenna 23075 (MBM, MO). Palmeira, Rod. do Café, Rio Tibagi, Hatschbach 11271 (F). Pinhaes, Dusén 7767 (S). Ponta Grossa, Dusén 2466 (S). RIO GRANDE DO SUL: São Francisco de Paula, Windisch 10004, Kerber \& Nervo (PACA). SANTA CATARINA: Chapecó; Faz. Campo São Vicente, $24 \mathrm{Km}$ W of Campo Erê, Smith et al. 9473 (HBR, US). Porto União, Fazenda Frei Rogério, $12 \mathrm{Km}$ SE of Porto União, Smith \& Reitz 8682 (US). Curitibanos, road Ponte Alta-Curitibanos, Km 3, Smith \& Klein 8259 (HBR, US). SÃO PAULO: Butantan, Hoehne 486 (GH, SP 3969, SP 486). São José dos Campos, 9.6 Km airline SSE of the city, Mimura 293 (GH, K, SP, US). Vila Mariana, near São Paulo, Wettstein \& Schiffner (P). São Bernardo do Campo, near São Paulo, Brade 5135 (HB). Mogi das Cruzes, Gehrt (SP 5488).

Distribution and habitat: Paraguay, Bolivia. In Brasil: States of Bahia, Goiás, Mato Grosso, Mato Grosso do Sul, Distrito Federal, Minas Gerais, São Paulo, Paraná, Santa Catarina, Rio Grande do Sul. Terrestrial, usually on wet or humid grasslands and swampy areas, on road banks, slopes, ledges, grasslands, dunes, "restinga" formations, alt. sea level to ca. $1300 \mathrm{~m}$ frequently on bare soil covered by blue-green algae.

Pseudolycopodiella carnosa is easily recognized by the characteristic bare, fleshy creeping stems. The stems are very brittle, densely and firmly attached to the soil, so most herbarium collections are somewhat fragmented.

Pseudolycopodiella sarcocaulon (Kuhn) Holub (= Lycopodium carolinianum L. var. grandifolium Spring) from Southern Africa is very similar to $P$. carnosa with respect to the fleshy stems and either is a close relative or a similar adaptation.

Pseudolycopodiella contexta (Mart.) Holub, Folia Geobot. Phytotax. 26: 93. 1991. Fig. 11e-h Lycopodium contextum Martius, Icon. Crypt. Brasil. 38, t. 20, f. 1. 1834. - Lycopodium alopecuroides L. var. contextum (Martius) Baker, Handb. Fern Allies 19. 1887. - Lycopodium alopecuroides L. subsp. contextum (Martius) Hassler, Trab. Inst. Bot. Farm. Buenos Aires 45: 92. 1928. - Lepidotis contexta (Martius) Rothm., Feddes Repert. 54: 66. 1944. - Lycopodiella contexta (Mart.) Holub, Folia Geobot. Phytotax. 18: 441. 1983. Type: In campis graminosis apricis in summo monte Arara-Coára, fluvii Japura cataractae imminente, alt. ca. 1200 p., Martius s.n. (M holotype!).

Lycopodium sprucei Baker, Handb. Fern Allies 24. 1887. - Type: Venezuela, San Carlos del Rio Negro, Spruce 3151 (holotype, K!; isotype, BONN, frag. Herb. Nessel 200! p.p.).

Horizontal shoots closely appressed to the ground, to at least $30 \mathrm{~cm}$ long, rooted with short intervals, sparsely branched in the horizontal plane, bearing stiffly erect, dorsally arising, simple, or sometimes 1-2 times forked, to at least $40 \mathrm{~cm}$ tall, vegetative or strobiliferous aerial shoots. Horizontal shoots densely covered on all sides by uniform leaves, 3-7 $\mathrm{mm}$ in diam incl. leaves, stems excl. leaves $1-2.5 \mathrm{~mm}$ thick. Leaves of horizontal shoots uniform, somewhat upward secund, ascending, acicular. Aerial shoots 4-6 mm diam. incl. leaves, densely foliose, with radially arranged, uniform leaves. Leaves of aerial shoots borne in alternating low spirals or irregular whorls of $6-7,0.8-1.5(-2) \mathrm{mm}$ apart, forming 12-14 indistinct longitudinal ranks, terete at the base (or angular when dried), upward sometimes flattened, strongly upward curved from a strongly diverging to almost perpendicular base, 4-5 $(-7) \times$ ca. 0.5 $\mathrm{mm}$, with conspicuously acroscopically adnate and long decurrent leaf bases, with smooth margins. Strobili to $8 \mathrm{~cm} \times 3-4 \mathrm{~mm}$ diam. with appressed sporophylls, to $12 \mathrm{~mm}$ diam. with distended sporophylls. Sporophylls borne in alternating whorls of 4-5, forming 8-10 longitudinal ranks, subpeltate, with a basiscopic, compressed membranous wing on the stalk, the exterior face with widely triangular-ovate to ovate-lanceolate base and a long, narrow apex, 4.5-7 × 1-1.5 mm, with subentire to slightly erose-dentate margins at the base. Sporangia borne on the sporophyll base, reniform, isovalvate, $1-1.5 \mathrm{~mm}$ wide. 


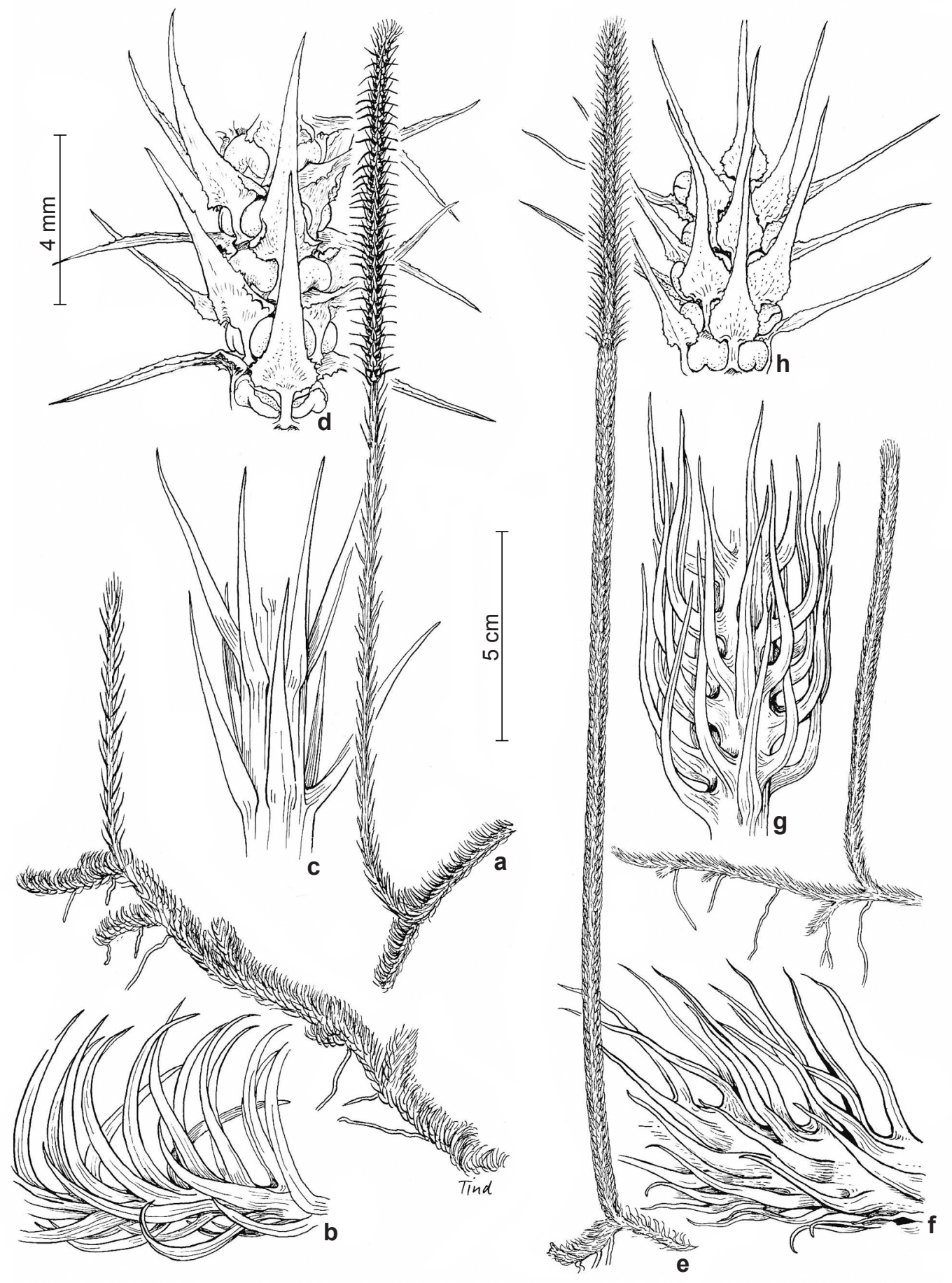

Figure 11 - a-d. Pseudolycopodiella iuliformis. Venezuela, Bolívar, Camarcaibarai-tepui Steyermark et al. 132065 (AAU). - a. growth habit; b. detail of prostrate shoot; c. detail of strobiliferous branch; d. detail of strobilus. e-h. Pseudolycopodiella contexta. Peru, Loreto, Río Nanay Foster 4102 (AAU). - e. growth habit; f. detail of prostrate shoot; g. detail of strobiliferous branch; h. detail of strobilus. 
Collections studied: BRAZIL. ACRE: Cruzeiro do Sul, Marinho 76 (NY). Cruzeiro do Sul, near new airport, Monteiro \& Damião 254 (INPA). AMAZONAS: Alto Rio Negro, Cucui, Serra de Tunui, Cavalcante 3057 (INPA, NY). On slope of Serra Aracá, Rosa \& Lira 2374 (NY). Cucurú, Rio Ayarí, Luetzelburg 22777 (R). Rio Cariua (Igarapé Branco) from Rio Curicuriari to Cachoeira de Bôto (C. Piraiuara), Poole 2009 (NY, US). Intica, Rio Uaupés, Luetzelburg 23041(R), 23614 (M, R, UC). PARÁ: Río Cururu Açu, Sick B-703 (HB). RONDÔNIA: Mutum Cavallo (Juruena-C. Novo), Hoehne 5372, 5373 (R).

Distribution and habitat: Circum-Amazonian, Amazonian lowland of Peru, Colombia and Venezuela. Brazil: Acre, Amazonas, Pará, Rondônia. Habitat: Terrestrial, humid places on white sand, grasslands and river margins, alt. $120-1750 \mathrm{~m}$.

Pseudolycopodiella iuliformis (Underw. \& Lloyd) Holub, Folia Geobot. Phytotax. 18: 442. 1983.

Fig. 11a-d

Lycopodium iuliforme Underw. \& Lloyd, Bull. Torrey Bot. Club 33: 120. 1906. - Lycopodiella iuliformis (Underw. \& Lloyd) B. Øllg., Opera Bot. 92: 176. 1987. - Type: Venezuela: Summit of Roraima, 8,600 ft. McConnel \& Quelch 572 (NY holotype).

Horizontal shoots closely appressed to the ground, at least to $20 \mathrm{~cm}$ long, rooted with short intervals, sparsely to densely branching in the horizontal plane, sometimes forming small mats, bearing stiffly erect, dorsally arising, simple, at least to $30 \mathrm{~cm}$ tall strobiliferous branches. Horizontal shoots densely covered on all sides by leaves, 7-10 $\mathrm{mm}$ diam. incl. leaves. Stems excl. leaves 1-3 mm thick. Leaves of horizontal shoots uniform, usually upward secund and curved, acicular, flattened with a subterete to compressed leaf base (angular when dried), or sometimes terete or angular throughout, 4-6 $\times 0.5-0.8(-1) \mathrm{mm}$, with smooth margins. Leaf bases not, or only slightly acroscopically adnate, short to long decurrent. Erect strobiliferous shoots 3-4 mm diam. incl leaves, 1.5-2 $\mathrm{mm}$ excl. leaves, with uniform, radially arranged leaves. Vegetative leaves of erect shoots borne in alternating, irregular whorls of 4-6, 2-4 mm apart, forming 8-12 obscure longitudinal ranks, appressed throughout, flattened, subulate, ca. $5 \times$ ca. $0.8 \mathrm{~mm}$, evenly tapering. Strobili at least to $11 \mathrm{~cm}$ long, $4-5 \mathrm{~mm}$ diam. with appressed sporophylls, to $14 \mathrm{~mm}$ in diam with distended sporophylls. Sporophylls borne in alternating whorls of 5-6, forming 10-12 longitudinal ranks, subpeltate, with a basiscopic, compressed membranaceous wing on the stalk, the exterior face with a widely ovate to rhombic basal part and an abruptly to evenly tapering, long apex, 5-8 $\times 1.5-2 \mathrm{~mm}$, with finely erose-dentate margins. Sporangia borne on the sporophyll base, reniform, isovalvate, $1.5-2 \mathrm{~mm}$ wide.

Collections studied: BRAZIL. AMAZONAS: Ridge line on Venezuela-Brazil border, Cerro Neblina, 1900-2100 m, Gentry \& Stein 46731 (AAU, MO). São Gabriel da Cachoeira, Alto da Serra da Neblina, Carvalho et al. 378 (BHCB). RORAIMA: Monte Roraima, Viana et al. 33464 (BHCB).

The description above covers only the Brazilian material. Pseudolycopodiella iuliformis is a highly variable species, confined to the Guyana Highlands. Brazil: Amazonas and Roraima.

Pseudolycopodiella meridionalis (Underw. \& Lloyd) Holub, Folia Geobot. Phytotax. 18: 442. 1983.

Fig. 10d-f

Lycopodium meridionale Underw. \& Lloyd, Bull. Torr. Bot. Club 33: 121. 1906. - Lycopodium carolinianum L. var. meridionale Nessel, Arch. Bot. Est. S. Paulo 1: 431. 1927. - Lycopodiella caroliniana (L.) Pichi-Sermolli var. meridionalis (Underw. \& Lloyd) B. Øllg. \& Windisch, Bradea 5: 27. 1987. - Type: Puerto Rico: Dry savannahs, Luquillo Mountains, Percy Wilson 94 (NY! holotype, US, isotype).

Terrestrial, with horizontal stems creeping and firmly rooted throughout, bearing one to few, dorsally arising, stiffly erect, simple, strobilus-bearing branches (peduncles). Creeping shoots to ca. $30 \mathrm{~cm}$ long, sparsely and unequally branched, 7-12 (-15) $\mathrm{mm}$ wide incl. leaves, $1-2 \mathrm{~mm}$ thick excl. leaves, anisophyllous, with long and wide lateral leaves, and usually shorter and narrower dorsal leaves; lateral leaves 3-5 (-7) × (1-) 1.5-2.5 (-3) mm, varying from widely triangular-ovate to lanceolate (sometimes in the same individual), obliquely spreading to falcately recurved, usually with a strongly curved, underlying acroscopic margin, and short to long decurrent basiscopic margins, tapering into an acute to long pointed apex, flat, with smooth margins. Dorsal leaves arranged in (1-) 2-4 longitudinal ranks (often on the same individual), widely lanceolate to subulate (rarely triangular-ovate), diverging to appressed, straight to upward curved, (1.5-) 3-4 (-5) $\times 1-1.3(-2) \mathrm{mm}$. Erect branches at least to $30 \mathrm{~cm}$ tall incl. the strobilus, $1-1.5 \mathrm{~mm}$ thick excl. leaves, terete, bearing small, 3-5 mm long, acicular leaves in remote, alternating spirals or irregular whorls of 4-5, these 4-8 mm apart. Strobili to at least $13 \mathrm{~cm}$ long, 3-5 mm thick with appressed sporophylls, 8-10 (-12) mm diam. incl. spreading sporophyll 
tips. Sporophylls borne in alternating whorls of 4 or $5(-6)$, forming 8-10 (-12) longitudinal ranks, subpeltate, with a thin, median, basiscopic, decurrent wing; the exterior face rhombic or ovate-acuminate or ovate-cuspidate to triangularlanceolate, 3.5-6 × (1-) 1.5-2 (-2.5) mm, with subscarious, entire to erose-denticulate, minutely fimbriate-denticulate margins. Sporangia reniform, isovalvate, ca. $1.5-2 \mathrm{~mm}$ wide.

Reference specimens (more than 100 studied, complete listing available from the main author): BRAZIL. AMAPÁ: $105 \mathrm{Km}$ E of Porto Grande, Austin et al. 7128 (F, US). AMAZONAS: Road to Igarapé, Preto ca. $60 \mathrm{Km}$ SE of Transamazonica highway, Calderon et al. 2736 (K, US). Manaus, Igarapé afluente Canãn, N of Maú, Rodrigues 138 (US). Rio Cuieiras, igarapé da Cachoeira, Rodrigues 6045 (F). BAHIA: Abaíra, Tijuquinho, Sano \& Loessøe 52303 (K). Serra do Tombador, Rio Ferro Doido, ca. $18 \mathrm{Km}$ E of Morro do Chapéu, 1100 m, Irwin et al. 32502 (F, K, US, Z). Ilhéus, road Olivença-Una, $2 \mathrm{Km} \mathrm{S}$ of Olivença, Boom et al. 718 (NY). Maraú, road Ubaitaba-Maraú, 45-50 Km E of Ubataiba, Mori et al. 11951 (F). Coastal zone, N from turning to Maraú, along Campinha road, Harley et al. 22165 (AAU, K). SW of Belmonte on road to Itapebi, 24.III.1974, Harley et al. 17379 (K, P). Coastal Zone, $11 \mathrm{Km} \mathrm{S}$ of Sta Cruz Cabrália, Harley et al. 17113 (K, P, US). GOIÁS: Gardner 3562 (K). MARANHÃO: Teresina-Caixas, Schwacke 154 (RB). MINAS GERAIS: Planalto of Serra do Cipó, $85 \mathrm{Km}$ NNE of Belo Horizonte, road Lagoa SantaConceição do Mato Dentro, Tryon \& Tryon 6810 (GH). Parque Florestal de Ibitipoca, at Córrego do Monjolinho, coming from Prainha, Novelino et al. 1091 (AAU). Cocaes, Serra do Garimpo, Hoehne (SP4982). Parque Nacional do Caparaó, Terreirão, 2400 m, Krieger et al. CESJ 24165 (AAU). Ouro Preto, access road to Cachoeiras das Andorinhas, 1330 m, Windisch 4958 (AAU). PARÁ: Vigia, $36 \mathrm{Km}$ SE of Vigia, along road to Belém, Davidse et al. 17573 (F). Maicurá, Curral Velho-Passagem Nova, Black 55-18766 (P). Trombetas, Rio Ariramba, campo da Tabuleta, Egler 419 (HB). PARANÁ: Serra do Mar, Quatro Barras-Morretes, $800 \mathrm{~m}$, Windisch et al. 4887 (AAU, SJRP). Jacarehy, Dusén 16715 (S, US). Serra do Mar, Ipiranga, Dusén 6532 (S). PERNAMBUCO: Prazeres, Pickel 3339 (US). PIAUÍ: Serra da Lua, Gurupy, Luetzelburg 21251 (M, R). Brejo do Correio", Luetzelburg 18872 p.p. (M). RIO DE JANEIRO: Alto da Tijuca, Hoehne (SP 24623). Serra dos Orgãos, Morro Assú, 2400 m, Luetzelburg 6233 b(M). Paineiras to Corcovado summit, 465-710 m, Smith 1247 (C, US). Alto Macahé, Glaziou 17964 (K, P). Boa Vista, between Tijuca and road to Macaco, Glaziou 7963 (C, P). Itatiaia, Haut-Itatiaia, Glaziou 5229 (P). SW of source of Rio Soberbo, Glaziou 4467 (C, K, P). Serra dos Orgãos, Teresópolis, Glaziou 4466(C, P). RIO GRANDE DO SUL: Porto Alegre, near Cascatas, Stier in Ros. Fil. Austrobras. 177 (E, GH, K, L, M, P, S, UC, US). Sapucaia, Reitz H134 (RB). Santa Maria, Malme 1232 (S). Ferromeco, Kunert 25 (US). RORAIMA: Serra dos Surucucus, Prance et al. 9885
(COL, K, S, US). SANTA CATARINA: Campo Alegre, slopes of Morro Iquererim, Reitz \& Klein 6420 (HB, HBR, US). Içara, Rincão, road to Rio Torneros (litoral), Windisch 4136 (AAU, SJRP). Ilha da Sta. Catarina, Canas Vieiras, Rohr1018 (HB). Porto União, Faz. Frei Rogerio, 12 Km SE of Porto União, Smith \& Reitz 8682 (HBR). Monte Cristo, Garuva, S. Francisco do Sul, Reitz \& Klein 5862 (HB, HBR, US). Palhoça, São Bonifácio, Rohr 1087 (RB). Mafra, Reitz 5270 (HBR). Itajaí, Ule 2160 (HBG) 160 (C, HBG, P). Lages, 1921, Spannagel 352 (S). SÃO PAULO: São Paulo, Morro Jaraguá, am Gipfel, 1100 m, Brade 5136 (HB, S). São Bernardo do Campo, Roadside along highway, Closer SP 77232 (SP, US). Serra da Bocaina, Barreiro Co. Lageado Farm, 1600 m, Segadas-Vianna 2772 (US). Mogí das Cruzes, Est. Biol. de Boraceia, Lima \& Torgo 13 (HB). Near Rio Grande, at São Paulo Railway, Wettstein \& Schiffner 971 (P, W). Campos do Jordão, limit with Pindamonhangaba, São José dos Alpes, 1800 m, Windisch 6814 (AAU). Santo André, Campo Grande, 800-900 m, Smith 1986 (C, K, S, US). Peruibe, litoral Sul do Estado, estrada Itanhaém-Peruibe Km 120, Siegel 6 (HB).

Distribution and habitat: Widely distributed in tropical America, but rare in the Andes. Ecuador, Peru and Venezuela, south to Argentina (Concepción). Brasil: states of Roraima, Amapá, Amazonas, Maranhão, Piauí, Pernambuco, Bahia, Goías, Minas Gerais, Rio de Janeiro, São Paulo, Paraná, Santa Catarina, Rio Grande do Sul. Terrestrial or sometimes epilithic, usually on moist or wet ground, on road banks, slopes, ledges, grasslands, dunes, restinga, alt. sea level to ca. $1300 \mathrm{~m}$.

Pseudolycopodiella paradoxa (Mart.) Holub, Folia Geobot. Phytotax. 18: 442. 1983.

Fig. 10a-c

Lycopodium paradoxum Mart., Icon. Pl. Crypt. Brasil., 38, t. 20, f. 2. 1838. - Lycopodium carolinianum L. var. paradoxum (Mart.) Christ, in Schwacke, P1. Nov. Mineiras 2: 42. 1900. Lycopodium carolinianum L. subsp. paradoxum (Mart.) Hassler, Trab. Inst. Farm. Buenos Aires 45: 93. 1928. - Lycopodiella caroliniana (L.) Pichi Sermolli var. paradoxa (Mart.) B. Øllg. \& Wind., Bradea 5: 27. 1987. - Type: Crescit in Brasiliae prov. Sebastianopolis in sylvis montanis, 1817 , Martius, Iter Brasiliense (M, holotype).

Lycopodium carolinianum L. var. springii Christ, Denkschr. Kaiserl. Akad. Wiss., Mat.-Nat. K1. 79: 59. 1908. - Type: Rio Grande, São Paulo Railway, Wettstein \& Schiffner s.n. (W not seen, P herb. Christ, BONN, herb. Nessel).

Creeping shoots 3-6 (-7) mm wide incl. leaves. Stem $1 \mathrm{~mm}$ or less thick excl. lateral leaves. Lateral leaves $2-3(-3.5) \times 1.5-2(-2.5) \mathrm{mm}$, usually widely obliquely triangular-ovate or widely 
lanceolate to almost dimidiate, somewhat falcately recurved, with a strongly convex acroscopic margin, acute to subobtuse. Dorsal leaves usually close and imbricate, arranged in 1-3 longitudinal ranks (often on the same individual), widely ovate to ovate-acuminate, $1-2 \times$ ca. $0.8-1.5 \mathrm{~mm}$. Erect branches to $10(-13) \mathrm{cm}$ tall incl. the strobilus, 1 mm or less thick excl. leaves, bearing small (ca. 2-3 $\mathrm{mm}$ long) subulate leaves in remote, alternating, irregular whorls of 3-4 (-5). Strobili to $6 \mathrm{~cm}$ long, ca. 2.5-3.5 mm thick with appressed sporophylls, ca. 5-7 mm thick including spreading sporophylls. Sporophylls borne in alternating whorls of 3-4 (-5), forming 6-8 (-10) longitudinal ranks, with a widely rhombic-ovate or triangular-ovate, acuminate to long-cuspidate exterior face, $3-4(-5) \times$ ca. 1.5-2.5 $\mathrm{mm}$, with minutely fimbriate-denticulate margins. Sporangia ca. $1.5 \mathrm{~mm}$ wide.

Reference specimens (more than 40 collections studied, complete listing available from the main author): BRAZIL. ACRE: Rio Manso, Hoehne 4026 (R). DISTRITO FEDERAL: Rio Vicente Pires, near EPNB, Shimabuko (UB). Parque Municipal do Gama, ca. $20 \mathrm{Km}$ S of Brasília, Irwin \& Soderstrom 5823 (F). Bacia do Rio S. Bartolomeu, Heringer et al. 4711 (MO). GOIÁS: Caiapônia-Jataí, Km 45, Hunt 6274 (US). Chapada dos Veadeiros, $27 \mathrm{Km}$ by road N of Alto Paraiso, Anderson 6731 (AAU, F, GH, UB). Serra dos Cristais, ca. $4.5 \mathrm{Km}$ NE of Cristalina, 1180 m, Anderson 8222 (K, UC, UB, US). Serra Dourada, ca. $15 \mathrm{Km}$ airline $\mathrm{S}$ of Goiás Velho, Anderson 10064 (AAU, F, GH, K, UB, US). Contraforte Central, ca. $24 \mathrm{Km}$ NE of Catalão, $875 \mathrm{~m}$, Irwin et al. 25406 (UB). MATO GROSSO: Cuiabá, Chapada dos Guimarães, Windisch 5380 (AAU, SJRP). Alto Araguaia, base of Serra Preta, near Burití, 500 m, Windisch 5357 (AAU, SJRP). Canarana, bacia do Rio Xingu, BR-158, ca. $2 \mathrm{Km} \mathrm{N}$ of access to Canarana, 5943 (AAU, SJRP). MATO GROSSO DO SUL: Corumbá, Smith 4699 (SP). MINAS GERAIS: Jaboticatubas, Serra do Espinhaço, Serra do Cipó, $1.4 \mathrm{Km}$ N of Chapeu do Sol, Eiten \& Eiten 6762 (SP, US). $4 \mathrm{Km} \mathrm{S}$ of Ouro Preto, Tryon \& Tryon 6892 (GH). São João d'El Rei, Glaziou 17963 (P). Lima Duarte, Monjolinho, - Serra da Ibitipoca, Magalhães 548 (HB) São Sebastião do Paraíso, Leito do Córrego do Baú, Brade 17933 (AAU, HB). Santana do Riacho, road Lagoa Santa-Conceição do Mato Dentro, Km 113, Serra do Cipó, corrego do Vitalino, 4340'W 19²0'S, 1150 m, Prado et al. 67 (AAU). PARANÁ: Rio Papagaios, Campo Largo, Hatschbach 320 (US). Serrinha, Dusén 15161 (S). Campo Largo, Rio Papagaio, Pereira 5464 (HB). SANTA CATARINA: Joinvile, Ule 2001 (HBG). Campo Novo, Mafra, 800 m, Reitz \& Klein 4860 (HBR, US).

Distribution and habitat: Roraima sandstone formation of Venezuela, savanna region of Colombia, Paraguay, and the Brazilian Planalto. Open, wet localities on sandy soil, river margins,
700-1750 m alt., in the states of Acre, Mato Grosso, Mato Grosso do Sul, Goiás, Distrito Federal (Brasília), Minas Gerais, São Paulo, Paraná, Santa Catarina. Habitat: Open, wet localities on sandy soil, river margins, 700-1750 m alt.

Similar to Pseudolycopodiella meridionalis in most features, but differs in the much smaller average size, and the proportions of the lateral and dorsal leaves.

Some specimens, e.g. Windisch 5380, and 5943 from Mato Grosso, seem intermediate to $P$. meridionalis, due to a more elongate growth habit.

Pseudolycopodiella squamata B. Øllgaard \& P.G. Windisch, sp. nov.

Fig. 12

Diagnosis: Species nova Pseudolycopodiella tatei et $P$. carnosae affinis a quibus differt foliis dorsalibus caulis horizontalis valde adnatis squamiformibus, marginibus decurrentibus foliorum basium distincte marcatis.

Type: Brazil, estado de Mato Grosso, mun. Cuiabá, Complexo da Chapada dos Guimaraes, caminho de acsesso ao Véu da Noiva. Campo. Local húmido con afloramento de água. Terrestre, verde oscuro (mais opaco que L. carnosa), folhas adpressas, crescendo junto com 5378 (L. carnosa) e por vezes entremeada com a mesma, ca. 550 $\mathrm{m}$ alt. 25.I.1989, P.G. Windisch 5379 (AAU, holotype; HB, isotype)

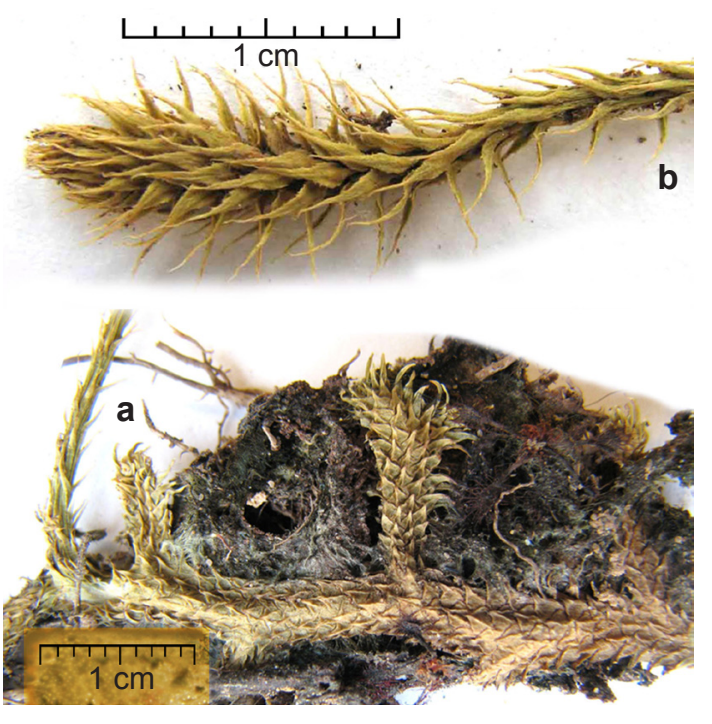

Figure 12 - Pseudolycopodiella squamata. Brazil, Mato Grosso, Chapada dos Guimaraes, Windisch 5379 (AAU). - a. prostrate stems; b. strobilus. 
Horizontal shoots creeping, the stem flattened and fleshy, firmly rooted, sparsely irregularly ramified, to $15 \mathrm{~cm}$ long, 7-12 (-20) $\mathrm{mm}$ wide incl. leaves, anisophyllous, with the lateral leaves long, the dorsal leaves shorter with widened, contiguous bases, covering the stem surface completely. Lateral leaves $2-5(-7) \times 0.8-2(-2.5) \mathrm{mm}$, narrowly triangular-lanceolate to acicular apically (sometimes angular in dried material); dorsal leaves borne in 3-4 longitudinal ranks, subulate, with widened bases, sometimes flattened, appressed, contiguous, 1.8-2.5 $\times$ ca. $1.5-2 \mathrm{~mm}$. Ventral side of stem with reduced, delicate, translucid, linear-lanceolate, leaves 1.5-2.5 $\times 0.3-0.5 \mathrm{~mm}$ (dried). Erect branches 7-14 cm long, incl. strobilus, $1.2-2 \mathrm{~mm}$ thick excl. leaves, with linear-lanceolate, basally slightly denticulate leaves, 3-4.5 × 0.7-1 mm, borne in irregular whorls of 5-7. Strobili $2.5-6 \mathrm{~cm} \times$ ca. $4.5 \mathrm{~mm}$ incl. appressed sporophylls, ca. 7-11 mm with distended sporophylls. Sporophylls borne in alternating whorls of 3-4, forming 6-8 longitudinal ranks, with ovaterhombic external face with long-acuminate apex, 4-6.5 × ca. $1-1.5 \mathrm{~mm}$, irregularly denticulate. Sporangia ca. $0.8-1.2 \mathrm{~mm}$ wide.

Collections studied: MATO GROSSO, Cuiabá, Complexo da Chapada dos Guimarães, at access road to

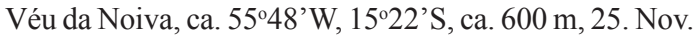
1989, Windisch 5826 (HB, SP).

Distribution and habitat: Endemic to the State of Mato Grosso. In grassland with Iridaceae, Eriocaulaceae, and Drosera, on bare soil with seeping water, and sometimes inundated by water, 600-700 m alt.

Pseudolycopodiella squamata grows locally intermixed with $P$. carnosa and $P$. tatei. In the field the three species can easily be recognized. In $P$. squamata the dorsal leaves have contiguous, clearly delimited, dark green leaf bases covering the stem surface completely, whereas in P. carnosa the dorsal leaves are distant, uncovering the pale green, fleshy stem surface. The strobili of $P$. squamata are smaller than those of $P$. carnosa.

All paratypes of Lycopodiella benjaminiana P.G. Windisch (1991) belong to the present species.

Pseudolycopodiella tatei (A.C. Smith) Holub, Folia Geobot. Phytotax. 26: 93. 1991.

Figs. 13,14

Lycopodium tatei A.C. Smith, Bull. Torrey Bot. Club 57: 180. 1930. - Lycopodiella iuliformis (Underw. \& Lloyd) B. Øllg. var. tatei (A.C. Smith) B. Øllg., Amer. Fern J. 79: 153. 1989. - Type: British Guiana: Mount Roraima, at Philipp Swamp, 5100 5200 ft. 11 Nov. 1927, Tate 350 (NY holotype).
Lycopodium duidae A.C. Smith, in Gleason, Bull. Torrey Bot. Club 58: 311. 1931. - Type: Venezuela: Cerro Duida, Central Camp, $4800 \mathrm{ft}$., Tate 1010 (NY holotype).

Lycopodiella benjaminiana P.G. Windisch, Bradea 6: 22, Figs. 1-5, 1991. - Type: Brasil, Estado de Mato Grosso, município de Alto Garças, (limite com Pedra Preta), estrada para Itiquira, via Fazenda Ponte de Pedra, Serra da Saudade. ca. $21 \mathrm{Km}$ da BR 364 , ca. 5350'W, 16 ${ }^{\circ} 50^{\circ} \mathrm{S}$, ca. 600-700 m alt., região de cerrado com afloramentos rochosos, vale com vereda e buritis, no campo junto a buritizal, solo encharcado. 18.VII.1991, Windisch 6291 (HB holotype; UFMT, US isotypes). - Pseudolycopodiella benjaminiana (P.G. Windisch) B. Øllg., Rodriguesia 63: 481. 2012.

Horizontal shoots closely appressed to the ground, at least to $20 \mathrm{~cm}$ long, rooted with short intervals, sparsely to densely branching in the horizontal plane, sometimes forming small mats, bearing stiffly erect, dorsally arising, simple, at least to $30 \mathrm{~cm}$ tall strobiliferous branches. Horizontal shoots densely covered on all sides by leaves, 7-13 $\mathrm{mm}$ diam. incl. leaves. Stems excl. leaves 2-4 (-5) $\mathrm{mm}$ thick (dried), swollen and sometimes flattened above. Leaves of the upper side of horizontal shoots uniform or the lateral ones somewhat widened at the base, usually upward secund and curved, acicular with a subterete to compressed leaf base (angular when dried), or sometimes

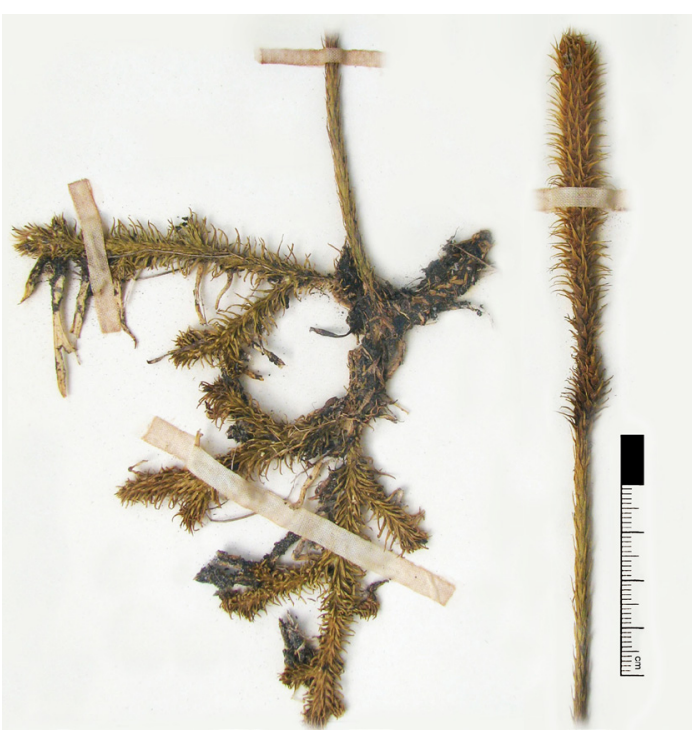

Figure 13 - Pseudolycopodiella tatei. Venezuela, Auyan-tepui, Guayaraca, Schnee 1449 p.p. (VEN), growth habit. 
terete or angular throughout, 4-9 × 0.5-0.8 $(-1.5)$ $\mathrm{mm}$, with smooth margins. Stem surface readily visible between leaf bases. Leaf bases slightly or not acroscopically adnate, short to long decurrent. Leaves of stem underside pale and membranaceous, to ca. $3 \mathrm{~mm}$ long. Erect strobiliferous shoots 3-5 $\mathrm{mm}$ diam. including leaves, $1.5-2.5 \mathrm{~mm}$ excluding leaves, with uniform, radially arranged leaves. Vegetative leaves of erect shoots borne in alternating, irregular whorls of 3-5, 2-4 mm apart, forming 6-10 obscure longitudinal ranks, appressed to slightly diverging throughout, flattened, subulate, 4-7 $\times 0.5-1 \mathrm{~mm}$, evenly tapering, with smooth to slightly denticulate margins. Strobili to $11 \mathrm{~cm}$ long, 4-6 mm diam. with appressed sporophylls, to 15 $\mathrm{mm}$ diam. with distended sporophylls. Sporophylls borne in alternating whorls of 4-6, forming 8-12 longitudinal ranks, subpeltate, with a basiscopic, compressed membranaceous wing on the stalk, the exterior face with a widely ovate to rhombic basal part and an abruptly to evenly tapering, long apex, 4-8 $\times 1.5-2.5 \mathrm{~mm}$, with finely erose-denticulate margins. Sporangia ca. $1.5 \mathrm{~mm}$ wide.

Collections studied: BRAZIL. BAHIA: Rio de Contas, Pico das Almas, E slope, Trilha Faz. Silvina-Queiroz, 1400-1500 m, Harley et al. 25578 (AAU). MATO GROSSO: Alto Garças (limite com Pedra Preta) estrada para Itiquira, Serra da Saudade, Windisch 6290 (AAU). MINAS GERAIS: São Gonçalo do Rio Preto, PE do Rio Preto, trail to Córrego das Éguas e o Morro do Alecrim, 1289 m, Almeida 792 et al. (photo ex BHCB). Catas Altas, Serra do Caraça, Mota \& Morais 1979 (photo ex BHCB).

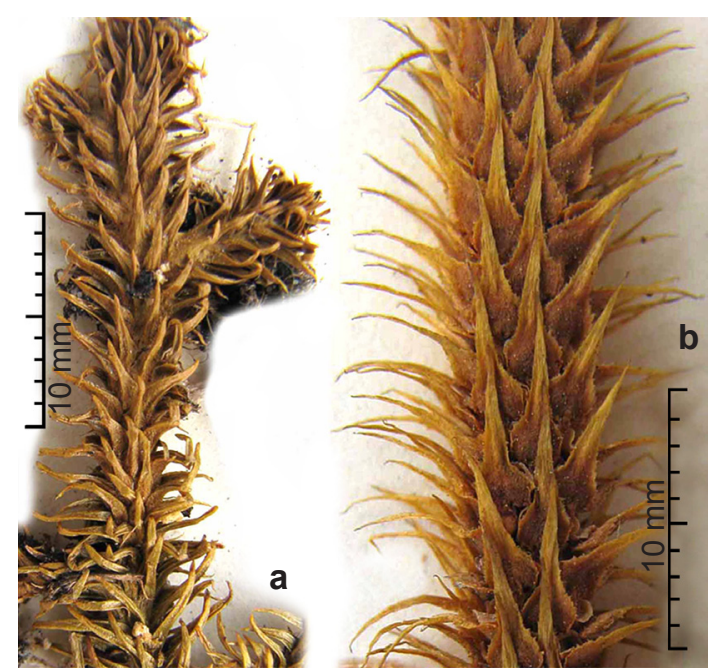

Figure 14 - Pseudolycopodiella tatei. Venezuela, Auyan-tepui, Guayaraca, Schnee 1449 p.p. (VEN). - a. detail of prostrate shoot; b. part of strobilus.
Catas Altas, P.N. do Caraça, trail to Pico do Sol, 1700 m, Salino et al. 6841 (photo ex BHCB). Felício dos Santos, APA Felício, Mata do Isidoro, surroundings of PE do Rio Preto, near Pico Dois Irmãos, Salino 9898 et al. (photo ex BHCB). Salino et al. 9963 (photo ex BHCB). PIAUÍ: "Piauhy: Brejo do Correio", Luetzelburg 18872 p.p. (M). RORAIMA: Vicinity of Auarís, upper slopes of Serra Parima, S of Auaris, 1400-1520 m, Prance et al. 9791 (K, M, S, US).

Distribution and habitat: Venezuelan Guiana. Guyana, Brazil: Roraima, Piauí, Mato Grosso, Minas Gerais. Humid campo limpo, and rupestre, humid stream banks, and seepage bogs, alt. 560-1700 m.

This is distinguishable from Pseudolycopodiella iuliformis by its swollen and spongy horizontal stems. It occurs at lower elevations than that species. The spongy character of rhizome may represent an adaptation to growth temporarily in shallow water.

A collection at W: São Paulo: Near Campo Grande between Santos and Sao Paulo, 750 m, Wettstein \& Schiffner s.n. (W p.p.) is mixed, mounted together with specimens of Pseudolycopodiella meridionalis, has dubious locality information, being far out of the central geographic and habitat range of P. tatei. The paratypes of Pseudolycopodiella benjaminiana are referred to $P$. squamata.

\section{Acknowledgements}

The authors thank the officers and staff of the herbaria consulted during this study, for the permission to study the material in their care. The first author is grateful for the valuable assistance of Dr. Lana Sylvestre and Dr. Claudine Mynssen at RB for their help during his studies there. The support from the Institute of Bioscience and the Herbarium of the Science Museums, University of Aarhus, and of the Universidade Estadual Paulista, Universidade do Vale do Rio dos Sinos, as well as grants from the Danish Natural Science Council and Brazilian Research Council (Conselho de Desenvolvimento Científico e Tecnológico $\mathrm{CNPq}$ ) were essential for the present study. Kirsten Tind prepared figures 5, 7d-f, 8, 9, and 11. Bent Johnsen prepared figures $7 \mathrm{a}-\mathrm{c}, 7 \mathrm{~g}-\mathrm{i}$.

\section{References}

Baker, J.G. 1887. Handbook of the fern-allies. George Bell \& Sons, London. 159p.

Ballard, F. 1950. Lycopodium carolinianum in Tropical Africa. American Fern Journal 40: 74-83.

Bruce, J.G. 1975. Systematics and morphology of subgenus Lepidotis of the genus Lycopodium (Lycopodiaceae). $\mathrm{Ph}$.D. thesis. University of Michigan. Xerox University Microfilms, Ann Arbor. Pp. 1-154. 
Bruce, J.G. 1976a. Comparative studies in the Biology of Lycopodium carolinianum. American Fern Journal 66: 125-137.

Bruce, J.G. 1976b. Gametophytes and subgeneric concepts in Lycopodium. American Journal of Botany 63: 919-924.

Christ, H. 1900. Spicilegium Pteridologicum AustroBrasiliense. In: Schwacke, W. (ed.). Plantas novas mineiras. Vol. 2. Imprensa Oficial, Ouro Preto. Pp. 12-42.

Christ, H. 1902. Lycopodiaceae. Spicilegium Pteridologicum Austro-Brasiliense. Bulletin de l'Herbier Boissier. ser. 2. 2: 699-708.

Christ, H. 1903. Lycopodiaceae. In: Chodat, R. \& Hassler, E. Plantae Hasslerianae, soit énumération des plantes récoltées au Paraguay par le Dr. Emile Hassler d'Aarau (Suisse). Bulletin de l'Herbier Boissier. ser. 2. 7: 620-621.

Christ, H. 1907. Pteridophyta. In: von Wettstein, R. Ergebnisse der botanischen expedition der Kaiserlichen Akademie der Wissenschaften nach Südbrasilien 1901, I. Band. Denkschrifte der Kaiserlichen Akademie der Wissenschaften, Matematisch-Naturwissenschaftliche Klasse 79: 1-53, T. I-IX.

Cranfill, R. 1981. Bog Clubmosses (Lycopodiella) in Kentucky. American Fern Journal 71: 97-100.

Fée, A.L.A. 1869. Cryptogames vasculaires (fougères, lycopodiacèes, hidropteridèes, equisetacèes) du Brésil. I. Partie. J.B. Baillière et. Fils: V. Masson et Fils, Paris. 346p.

Feé, A.L.A. 1873. Cryptogames vasculaires (fougères, lycopodiacèes, hidropteridèes, equisetacèes) du Brésil. II partie: Supplément et révision. J.B. Baillière, Paris. $115 \mathrm{p}$.

Greville, R.K. \& Hooker, W.J. 1831. Enumeratio Filicum, Part I. Lycopodineae. Botanical Miscellany 2: 360403.

Hassler, E. 1928. Pteridophytorum Paraguariensis et Regionum Argentinarum adyacentium conspectus criticus. Enumeración de las Pteridofitas del Paraguay, Misiones Argentinas y Gran Chaco conocidas hasta fines del año 1921. Trabajos del Instituto de Botanica y Farmacia de la Facultad de Ciencias Medicas de Buenos Aires 45: 1-102.

Herter, W. 1909. Beiträge zur Kenntnis der Gattung Lycopodium. Studien über die Untergattung Urostachys. Botanische Jahrbücher für Systematik, Pflanzengeschichte und Pflanzengeographie 43 Beiblätter 98: 1-56.

Herter, W. 1949: Heteropteridophyta aliquot nova vel critica. Revista Sudamericana de Botanica 8: 19-25.

Hieronymus, G. 1905. Plantae Lehmannianae in Guatemala, Columbia et Ecuador regionibus finitimis collectae, additis quibusdam ab aliis collectoribus ex iisdem regionibus allatis determinatae et descriptae. Pteridophytae. Botanische Jahrbücher für Systematik, Pflanzengeschichte und Pflanzengeographie 34: 561-582.
Holub, J. 1964. Lycopodiella, novy rod rádu Lycopodiales (Lycopodiella, eine neue Gattung der Ordnung Lycopodiales). Preslia 36: 16-22.

Holub, J. 1983. Validation of Generic Names in Lycopodiaceae: with a Description of a New Genus Pseudolycopodiella. Folia Geobotanica et Phytotaxonomica 18: 439-442.

Holub, J. 1985. Transfers of Lycopodium species to Huperzia: with a note on Generic Classification in Huperziaceae. Folia Geobotanica et Phytotaxonomica 20: $67-80$.

Holub, J. 1991. Some Taxonomic changes within Lycopodiales. Folia Geobotanica et Phytotaxonomica 26: 81-94.

Kornas, J. 1975. Tuber production and fire-resistance in Lycopodium carolinianum in Zambia. Acta Societatis Bototanicorum Poloniae 44: 653-663.

Lellinger, D.B. 1977. Nomenclatural and taxonomic notes on the pteridophytes of Costa Rica, Panama, and Colombia. Proceedings of the Biological Society of Washington 89: 703-732.

Linnaeus, C. von. 1753. Species plantarum, exhibentes plantas rite cognitas, ad genera relatas, cum differentiis specificis, nominibus trivialibus, synonymis selectis, locis naturalibus, secundum systema sexuale digestas. 2 vols. Impensis Laurentii Salvii, Holmiae. Tomus I: 1-560; II: 561-1200.

Martius, C.F.P. von (1828-) 1834. Icones Plantarum Cryptogamicarum quas in Itinere annis $1817-20$ per Brasiliam jussu et auspiciis Maximiliani Josephi I. collegit et descripsit ... 1-138, t. 1-76. Monachii.

Müller, K. 1861. Zur Kenntnis des Lycopodium cernuum L. Botanische Zeitung (Berlin) 19: 161-165.

Nessel, H. 1927. As Lycopodiáceas do Brasil. Archivos de Botânica do Estado de São Paulo 1: 355-535.

Nessel, H. 1939. Die Bärlappgewächse (Lycopodiaceae) Eine beschreibende Zusammenstellungmit besonderer Berücksichtigung ihrer Varietätet und Formen. G. Fischer, Jena. 404p.

Nessel, H. 1940. Beiträge zur Kenntniss der Lycopodiaceen. Revista Sudamericana de Botanica 6: 156-175.

Nessel, H. 1955. Lycopodiaceae. In: Hoehne, F.C. Vol. 11. Flora Brasílica II. Impres - Companhia Brasileira de Impresão e Propaganda, São Paulo. Pp. 1-131.

Øllgaard, B. 1979. Studies in Lycopodiaceae, II. The branching patterns and infrageneric groups of Lycopodium sensu lato. American Fern Journal 69: 49-61.

Øllgaard, B. 1987. A revised classification of the Lycopodiaceae sensu lato. Opera Botanica 92: 153-178.

Øllgaard, B. 1988. Lycopodiaceae. In: Harling, G. \& Andersson, L. Flora of Ecuador 33: 1-155.

Øllgaard, B. 1989. New taxa and combinations of Venezuelan Lycopodiaceae. American Fern Journal 79: 151-154.

Øllgaard, B. 2004. Novelties in neotropical Lycopodiaceae. Nordic Journal of Botany 23: 31-47. 
Øllgaard, B. 2012. Nomenclatural changes in Brazilian Lycopodiaceae. Rodriguésia 63: 479-482.

Øllgaard, B. 2014. Six new species and some nomenclatural changes in neotropical Lycopodiaceae. Nordic Journal of Botany 33: 186-196.

Øllgaard, B. \& Windisch, P.G. 1987. Sinopse das Licopodiáceas do Brasil. Bradea 5: 1-43.

Øllgaard, B. \& Windisch, P.G. 2014. Lycopodiaceae in Brazil. Conspectus of the family. I. The genera Lycopodium, Austrolycopodium, Diphasium and Diphasiastrum. Rodriguésia 65: 261-277.

Palisot de Beauvois, A.M.F.J. 1805. Prodrome des cinquième et sixième familles de L' Æthéogamie. Les Mousses. Les Lycopodes, Paris. Pp. 1-114.

Pichi Sermolli, R.E.G. 1968. Fragmenta Pteridologiae I. Webbia 23: 159-207.

Pritzel, E. 1900. Lycopodiaceae. In: Engler, A. \& Prantl, K. Die Natürlichen Pflanzenfamilien, Teil 1, Abt. 4. W. Engelmann, Leipzig. Pp. 563-606.

Proctor, G.R. 1977. Pteridophyta. In: Howard, R.A. Flora of the Lesser Antilles, Leeward and Windward Islands 2. Arnold Arboretum, Harvard University, Boston. Pp. 1-414.

Proctor, G.R. 1985. Ferns of Jamaica, a guide to the Pteridophytes. British Museum (Natural History), London. 631p.

Rosenstock, E. 1907. Beiträge zur Pteridophytenflora Südbrasiliens II. Hedwigia 46: 57-167.

Rothmaler, W. 1944. Pteridophyten-Studien, I. Feddes Repertorium specierum novarum regni vegetabilis 54: 55-82.

Silveira, A. 1898. Novae species Lycopodiacearum civitatis Minas Geraes, Brasil. Boletim da Commissão Geográfica e Geológica do Estado Minas Geraes 5: 117-145.
Smith, A.C. 1930. Notes on Pteridophyta from mount Roraima. Bulletin of the Torrey Botanical Club 57: 177-180.

Smith, A.C. 1931. Lycopodiaceae. In: Gleason, H. The TylerDuida Expedition. Bulletin of the Torrey Botanical Club 58: 277-344.

Sodiro, A. 1893. Cryptogamae vasculares quitenses adiectis speciebus in aliis provinciis ditionis ecuadorensis hactenus detectis. Typis Universitatis, Quito. Pp. 1-656.

Spring, A.F. 1838. Beiträge zur Kenntniss der Lycopodien. Flora 21: 145-158, 161-175, 177-191, 193-205, 209224.

Spring, A. 1842. Monographie de la famille des Lycopodiacées, premiére partie. Mémoires de l'Académie Royale des Sciences, Lettres et Beaux Arts de Belgique 15: 1-110.

Takamiya, M. \& Kurita, S. 1983. Cytotaxonomic studies on Japanese species of the genus Lycopodium sensu lato. Acta Phytotaxonomica et Geobotanica 34: 66-79.

Tardieu-Blot, M.L. 1970. A propos des Lycopodiales de la Région Malgache. Adansonia, ser. 2, 10: 15-22.

Underwood, L.M. \& Lloyd, F.E. 1906. The species of Lycopodium of the American tropics. Bulletin of the Torrey Botanical Club 33: 101-124.

Vasconcellos, J.C. \& Franco, J.A. 1967. Breves notas sobre Licopodiáceas. Boletim da Sociedade Brotheriana 41: 23-25.

Wagner, W.H.Jr. \& Beitel, J.M. 1992. Generic classification of modern North American Lycopodiaceae. Annals Missouri Botanical Garden 79: 676-686.

Walker, T.G. 1966. A Cytotaxonomic Survey of the Pteridophytes of Jamaica. Transactions of the Royal Society of Edinburgh 66: 169-237.

Windisch, P.G. 1991. Lycopsida austroamericana nova. Bradea 6: 21-24. 